\title{
Hot Summers: Effect of Extreme Temperatures on Ozone in Sydney, Australia
}

\author{
Steven R. Utembe ${ }^{1, *}$, Peter J. Rayner ${ }^{1}$, Jeremy D. Silver ${ }^{1}\left(\mathbb{D}\right.$, Elise-Andree Guérette ${ }^{2}{ }^{\circledR}$, \\ Jenny A. Fisher ${ }^{2}$, Kathryn M. Emmerson ${ }^{3}$, Martin Cope ${ }^{3}$, Clare Paton-Walsh ${ }^{2}{ }^{\mathbb{D}}$, \\ Alan D. Griffiths ${ }^{2,4} \mathbb{D}^{\text {, Hiep Duc }}{ }^{5} \mathbb{D}$, Khalia Monk ${ }^{5}$ and Yvonne Scorgie ${ }^{5}$ \\ 1 School of Earth Sciences, University of Melbourne, Parkville 3010, Victoria, Australia; \\ prayner@unimelb.edu.au (P.J.R.); jeremy.silver@unimelb.edu.au (J.D.S.) \\ 2 Centre for Atmospheric Chemistry, University of Wollongong, Wollongong 2522, New South Wales, \\ Australia; eag873@uowmail.edu.au (E.-A.G.); jennyf@uow.edu.au (J.A.F.); \\ clarem@uow.edu.au (C.P.-W.); agf@ansto.gov.au (A.D.G.) \\ 3 Oceans and Atmosphere, Commonwealth Scientific and Industrial Research Organisation (CSIRO), \\ Aspendale 3195, Victoria, Australia; Kathryn.Emmerson@csiro.au (K.M.E.); Martin.Cope@csiro.au (M.C.) \\ 4 Australia Nuclear Science and Technology Organisation (ANSTO), Sydney 2234, New South Wales, Australia \\ 5 Office of Environment and Heritage, Sydney 2000, New South Wales, Australia; \\ Hiep.Duc@environment.nsw.gov.au (H.D.); Khalia.Monk@environment.nsw.gov.au (K.M.); \\ Yvonne.Scorgie@environment.nsw.gov.au (Y.S.) \\ * Correspondence: steven.utembe@unimelb.edu.au; Tel.: +613-8344-9502
}

Received: 29 September 2018; Accepted: 21 November 2018; Published: 27 November 2018

check for updates

\begin{abstract}
Poor air quality is often associated with hot weather, but the quantitative attribution of high temperatures on air quality remains unclear. In this study, the effect of elevated temperatures on air quality is investigated in Greater Sydney using January 2013, a period of extreme heat during which temperatures at times exceeded $40{ }^{\circ} \mathrm{C}$, as a case study. Using observations from 17 measurement sites and the Weather Research and Forecasting Chemistry (WRF-Chem) model, we analyse the effect of elevated temperatures on ozone in Sydney by running a number of sensitivity studies in which: (1) the model is run with biogenic emissions generated by MEGAN and separately run with monthly average Model of Emissions of Gases and Aerosols from Nature ( MEGAN) biogenic emissions (for January 2013); (2) the model results from the standard run are compared with those in which average temperatures (for January 2013) are only applied to the chemistry; (3) the model is run using both averaged biogenic emissions and temperatures; and ( 4 and 5 ) the model is run with half and zero biogenic emissions. The results show that the impact on simulated ozone through the effect of temperature on reaction rates is similar to the impact via the effect of temperature on biogenic emissions and the relative impacts are largely additive when compared to the run in which both are averaged. When averaged across 17 sites in Greater Sydney, the differences between ozone simulated under standard and averaged model conditions are as high as 16 ppbv. Removing biogenic emissions in the model has the effect of removing all simulated ozone episodes during extreme heat periods, highlighting the important role of biogenic emissions in Australia, where Eucalypts are a key biogenic source.
\end{abstract}

Keywords: air pollution; ozone; extreme temperatures

\section{Introduction}

It is estimated that poor air quality is responsible for millions of premature deaths per year around the globe [1]. High levels of air pollution are usually caused by a combination of hot and usually, but not always, stagnant meteorological conditions as well as high emissions of the precursors 
of ozone and other pollutants, so that air pollution events are often associated with extreme heat periods [2,3]. Global warming is expected to increase the occurrence, intensity and persistence of future stagnation events around the world (e.g., [4,5]). Many studies have shown the negative implications of global warming for future air quality and its implications for increased mortality. For example, using nine climate-chemistry models, Silva et al. [6] showed that climate change will increase air pollution deaths by hundreds of thousands by 2100, with the greatest impact being in India and East Asia. Although the air quality in Australia is relatively good compared to the Northern Hemisphere [7,8], the study by Silva et al. [6] showed an increased risk under climate change conditions. Indeed, using temperature and air quality data collected between 1994 and 2004, Hu et al. [9] found that elevated daily maximum temperatures combined with high $\mathrm{SO}_{2}$ mixing ratios contributed to increased mortality in Sydney. Broome et al. [10] calculated that modest reductions in air pollution in Sydney had substantial health benefits. They found that only a 10\% reduction in $\mathrm{PM}_{2.5}$ exposure (using 2007 exposure data) would result in 650 fewer premature deaths over a period of 10 years.

A number of factors are thought to be responsible for increased air pollution during extreme temperature or heatwave conditions. These include the impact of temperature on emissions, temperature-dependent photochemical rate constants, the amount of light reaching the earth and the direct effect of meteorology. Under warmer conditions, emissions of ozone precursors such as biogenic emissions are enhanced due to their sunlight dependency as well as an exponential temperature dependency [11]. The warmer conditions also affect chemistry directly via altered reaction rates as most of the reactions that form ozone are characterised by rate constants with an exponential (Arrhenius type) dependence on temperature so that higher ozone mixing ratios are observed under warmer conditions [12]. Sillman and Samson [13] showed how the increase in ozone with temperature was largely driven by the chemistry of peroxyacetlynitrate (PAN), a sink for $\mathrm{NO}_{x}$ (i.e., $\mathrm{NO}+\mathrm{NO}_{2}$ ) and odd hydrogen at low temperatures. From a meteorological point of view, high temperatures are often due to high pressure systems, which in many cases bring clear skies, increased radiation which increases photolysis rates [14,15], increased surface heating and stagnant conditions that suppress pollutant advection. The scattering and absorption of radiation by aerosols can also influence radiation flux, which, in turn, affect photolysis rates (e.g., [16]). Thus, the enhanced emissions, increased photochemistry and stagnant conditions all combine to result in an accumulation of ozone and other pollutants near the surface [17].

Biogenic volatile organic compounds (VOCs), which have a much higher reactivity than anthropogenic hydrocarbons [18], can act as a sink or source of ozone depending on the availability of nitrogen oxides. In urban and suburban areas where significant $\mathrm{NO}_{x}$ is present, mainly from anthropogenic sources, these VOCs can undergo chemical transformation leading to build up of ozone and particulates in the planetary boundary layer (PBL). Like many areas in the Southern Hemisphere, Australian cities often present $\mathrm{NO}_{x}$-limited conditions $[19,20]$. Some of the larger cities in Australia are also surrounded by large forests dominated by Eucalyptus trees, which are among the highest emitters of biogenic VOCs, including isoprene and monoterpenes [21], such that there is a need to understand the impact of these substantial biogenic emission sources on the air quality in populated areas, especially under extreme warm episodes in view of future global warming. It is therefore instructive to analyse the relative impacts of biogenic emissions and temperature in driving poor air quality episodes. Knowing the relative importance of these two effects is necessary for focusing development effort appropriately between improvements to temperature forecasting or biogenic emissions. Moreover, knowing the relative impact of biogenic emissions can help inform policy in choice of tree types, especially in the urban environment. 
The impact of extreme temperatures on air quality through its effect on chemistry and biogenic emissions is studied in this paper by analysing a period of extremely high temperatures in Greater Sydney, New South Wales (NSW), Australia. Sydney, with a population of over 4 million, is a coastal city and is nestled between the sea to the east and the Blue Mountains to the north and north west. The Greater Blue Mountains Heritage Area covers over a million hectares with over $95 \%$ of the trees belonging to the Eucalyptus genus [22]. Almost 13\% of all Eucalyptus species in the world are found in this area alone (e.g., [23]).

We used the Weather Research and Forecasting chemistry and transport model (WRF-Chem) to simulate mixing ratios of ozone and other pollutants during extreme heat conditions in Sydney in January 2013. We compare the predicted mixing ratios (simulated under standard model conditions) with observations made at 17 sites across Sydney. We also present results from model sensitivity studies with altered biogenic emissions and temperature in order to compare them with those simulated under standard model standard conditions. In doing this, we hope to answer the following five questions:

(1) How different would ozone in Greater Sydney during the hot day episodes be under average biogenic emissions?

(2) How different would ozone be if the biogenic emissions were high but chemistry was normal (i.e., under average temperature conditions)?

(3) What would happen to ozone during the Sydney hot day episodes under both average emissions and average temperatures?

(4) What would happen to ozone if there were no biogenic sources of emissions?

(5) How do these scenarios differ from standard conditions?

In answering these questions, we gain insight into which factors drive the increased air pollution observed in Sydney during the extremely hot day episodes. As discussed above, this is helpful in concentrating efforts in model development. In addition, if biogenic emissions are the dominant cause of air pollution in an urban area, it may be possible to reduce emissions by altering the species of trees planted within the area, but changes in chemistry due to temperature increases may be beyond the control of any legislative changes.

The paper is organised as follows. In the next section (Section 2), the observations, model set-up and model sensitivity studies are presented. This is followed by Section 3 in which we present the results and discussion. Finally, in Section 4, we present the conclusions.

\section{Experimental Methods}

In this section, we describe the observations, the model setup and the rationale for the experiments conducted for this study. Greater Sydney is an ideal location for these simulations mainly because of the availability of a dense air quality monitoring network, its proximity to the biogenic sources in the Blue Mountains and the high temperatures experienced in January 2013.

\subsection{Observation Data}

We used hourly observations of $\mathrm{O}_{3}, \mathrm{NO}_{x}$, isoprene and formaldehyde (HCHO). Apart from isoprene and $\mathrm{HCHO}$, which are only recorded at a single site, the rest are obtained from 17 measurement sites located in the Greater Sydney area. The data are part of the measurement network that is run and maintained by the New South Wales (NSW) Office of Environment and Heritage (OEH). Isoprene and $\mathrm{HCHO}$ were measured using Proton-transfer-reaction mass spectrometry (PTR-MS) during the Measurements of Urban, Marine and Biogenic Air (MUMBA) campaign which was conducted by the University of Wollongong and CSIRO from December 2012 to the end of February 2013 [24]. A map showing the locations of the measurement sites is shown in Figure 1. 


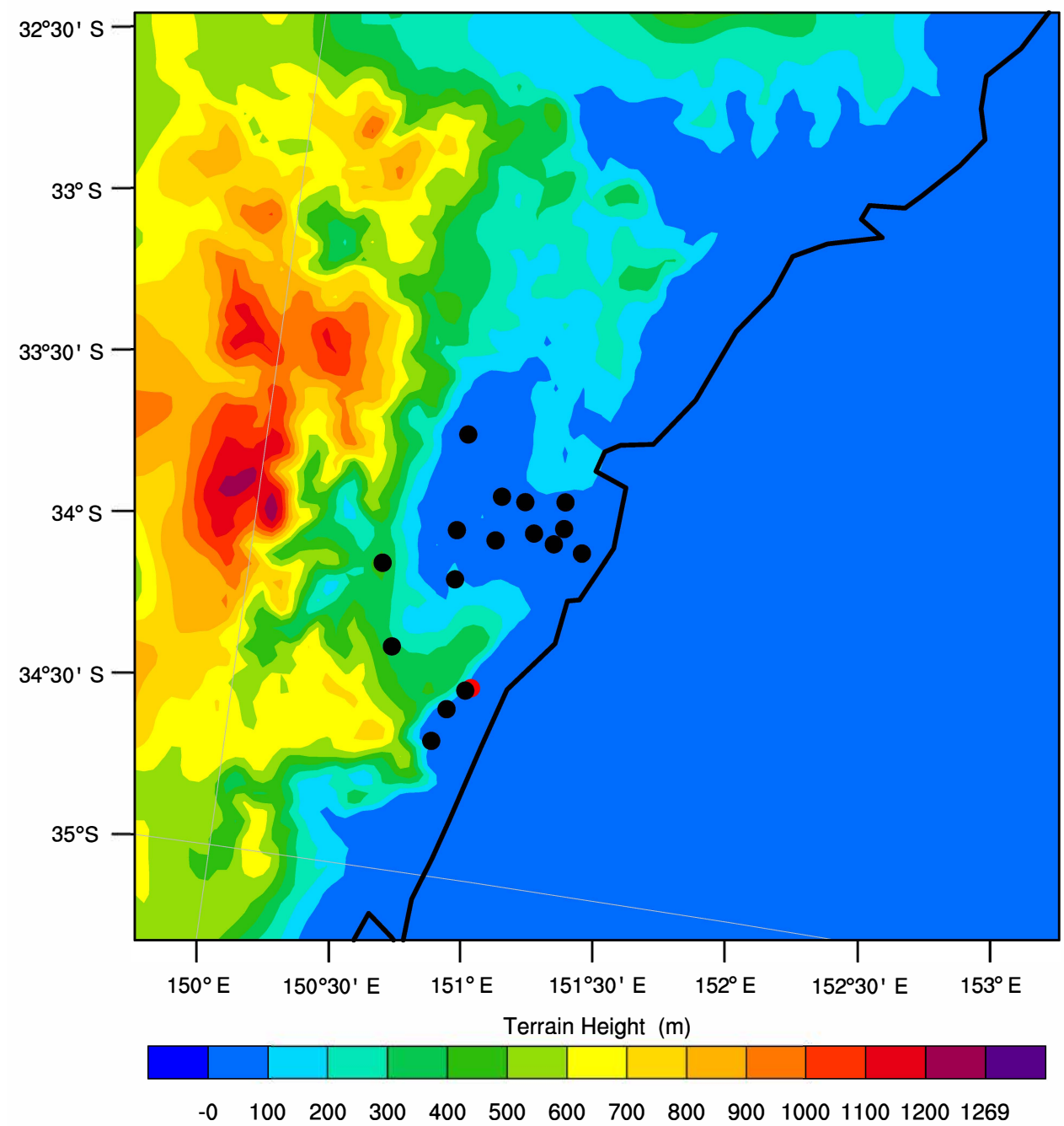

Figure 1. Terrain map of the model's innermost domain showing locations of measurements (dots). Site of isoprene and formaldehyde measurements shown as red dot.

\subsection{Model Setup and Domains}

WRF is a regional-scale atmospheric transport model that is widely used for atmospheric research as well as operational forecasting applications [25]. Its chemistry version (WRF-Chem) uses the Advanced Research WRF (ARW) dynamic core [26]. WRF-Chem is an online coupled model so that meteorological, chemical and aerosol fields are all integrated at the same time. The model was run without aerosol-radiation feedback in order to isolate the influence of temperature on chemistry and emissions apart from changes in photolysis rates due to aerosol-radiation feedback. For the purposes of this study, we have used version 3.7.1.

The Lambert conformal projection was used to map the model grid to the surface of the Earth. In the vertical, the model has 33 levels with increased vertical resolution in the first few levels in the boundary layer. As shown in Figure 2, our model domain setup is comprised of four nested domains with the outermost to innermost domains at a resolution of $81 \mathrm{~km}, 27 \mathrm{~km}, 9 \mathrm{~km}$ and $3 \mathrm{~km}$, respectively. The outermost domain covers the whole of Australia in order to capture regional influences. The innermost domain covers the Greater Sydney area, which is the focus of this study. 


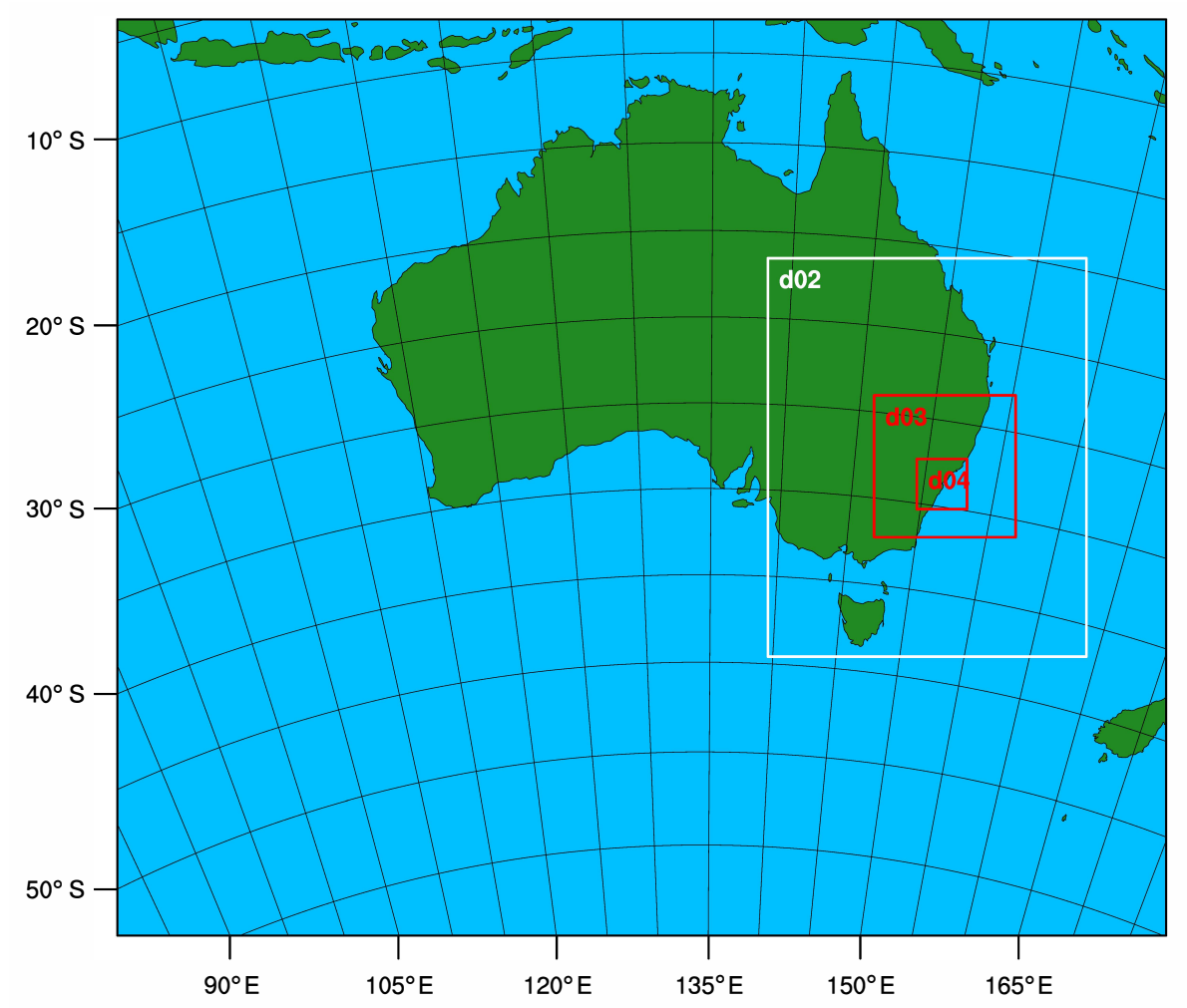

Figure 2. 4-nested domain set-up for WRF-Chem runs used in this study. Domain horizontal resolutions are $81 \mathrm{~km}$ (outermost), $27 \mathrm{~km}$ (d02, white box), $9 \mathrm{~km}$ (d03, red box) and $3 \mathrm{~km}$ (d04, red box).

Meteorological fields, initial and lateral boundary conditions were taken from ERA Interim re-analyses which have a horizontal resolution of $79 \mathrm{~km}$ [27]. Sea surface temperatures were taken from NOAA real-time global sea surface temperature analyses at $0.083^{\circ}$ resolution [28]. Initial and lateral boundary conditions for the mixing ratio fields were obtained from the global-scale Model for Ozone and Related chemical Tracers version 4 (MOZART) [29] at a 6-hourly resolution. WRF-Chem was run in a nudged mode to constrain the model towards re-analyses [30].

WRF-Chem can be run with a wide choice of physical and dynamical schemes. We used the NOAH land surface model [31], the Yonsei University (YSU) PBL scheme [32], the WRF single-moment 5-class Lin microphysics scheme [33] and the Rapid Radiative Transfer (RRTMG) radiation scheme [34]. A summary of physics schemes used in the model runs is presented in Table 1.

Table 1. Physics schemes used in WRF model set-up for Greater Sydney.

\begin{tabular}{ccc}
\hline Type & Selected Option & References \\
\hline Boundary Layer & YSU scheme & Hong et al. [32] \\
Land surface & NOAH land-surface model & Chen and Dudhia [31] \\
Surface layer & Monin-Obukhov (Janjic Eta) scheme & Monin and Obukhov [35] \\
Long-wave radiation & Rapid Radiative Transfer scheme & Mlawer et al. [34] \\
Short-wave radiation & Goddard shortwave scheme & Chou and Suarez [36] \\
Microphysics & WRF single-moment 5-class scheme (Lin) & Lin et al. [33] \\
Cumulus scheme & Grell 3-D ensemble scheme & Grell and Dévényi [37] \\
\hline
\end{tabular}

This study uses the Regional Atmospheric Chemistry Mechanism (RACM) of Stockwell et al. [38] for the gas phase chemistry scheme (with F-TUV photolysis scheme) and for the aerosol scheme it uses the Modal Aerosol Dynamics Model for Europe (MADE) which is coupled to a Secondary Organic Aerosol Module (SORGAM) [39,40]. 
Anthropogenic emissions (for 2008) of $\mathrm{CH}_{4}, \mathrm{CO}, \mathrm{NO}_{x}$, VOCs and particulates for the Greater Sydney area were provided by the NSW OEH at a grid resolution of $1 \mathrm{~km} \times 1 \mathrm{~km}$. Outside the Greater Sydney area, we have used EDGAR-HTAP (2008) emissions [41] which are available at a horizontal grid resolution of $0.1^{\circ} \times 0.1^{\circ}$. Dust and sea-salt emissions are proportional to wind speed at $10 \mathrm{~m}$ as parameterised from the GOCART model [42,43].

Biogenic emissions are generated from the Model of Emissions of Gases and Aerosols from Nature (MEGAN v2.1) model [44] using the default 24 category land use data from U.S. Geological Survey (USGS). Prior to the model run, we used the MEGAN preprocessor to read in pre-calculated emissions factors, leaf area index (LAI), plant functional type fractions, solar radiation and climatological temperatures maps from the MEGAN global model. These are used as input into the model which uses the temperature at $2 \mathrm{~m}$ and downward solar radiation to process the gamma values, which are used to calculate the explicit biogenic emissions.

In this study, we will not present results of aerosol simulations as they are discussed in a companion paper as part of this special issue.

\subsection{Model Scenarios}

In order to address the questions posed above, we ran a number of model scenarios. The first scenario is the base run (STD_ET; here STD stands for "standard" with the model set up as outlined above) in which the model is run with the actual simulated emissions and temperatures (ET). In the second scenario, denoted AVG_E, the model is run using WRF-Chem MEGAN simulated biogenic emissions which are averaged for the whole month of January 2013 (but include average diurnal variability). The third scenario is where WRF-Chem simulated average temperatures for January 2013 are used to estimate non-photolytic chemical reaction rates (denoted AVG_T) but standard time-varying temperatures are used to calculate biogenic emissions. Since temperature and other meteorological fields such as pressure and humidity are coupled together, we applied the average temperatures to the chemistry only so that the dynamics of the model remain unchanged. For this study, we have assumed that under average temperature conditions, a change in water vapour does not significantly affect $\mathrm{OH}$ concentrations that are produced from photolysis of water. In the fourth sensitivity study (AVG_ET), we have applied both averaged biogenic emissions and average temperatures. We also conducted two further sensitivity studies, in which the biogenic emissions were zeroed (ZERO_B) and halved (HALF_B). The scenarios are summarised in Table 2. The model scenarios were run from the 5th to 20th of January 2013 with the first two days used for model spin-up.

Table 2. Summary of sensitivity studies used in this study.

\begin{tabular}{cc}
\hline Scenario & Description \\
\hline STD_ET & Standard model run \\
AVG_E & Average biogenic emissions \\
AVG_T & Average temperature (chemistry only) \\
AVG_ET & Average of both biogenic emissions and temperature \\
ZERO_B & Zero biogenic emissions \\
HALF_B & Half biogenic emissions \\
\hline
\end{tabular}

\section{Results and Discussion}

Since accurate simulation of temperature, wind speed and wind direction is critical for the accurate simulation of surface ozone and other trace gases, it is instructive to evaluate model performance of meteorology. Thus, in this section, we will first assess model skill in simulating observed meteorology before evaluating the model simulation of surface pollutants. Finally, we will examine the model scenarios. 


\subsection{Simulation of Observed Meteorology}

January 2013 was an extreme month for Sydney in terms of both high temperatures and high rainfall with conditions so severe that the 2013 summer was also dubbed the 'angry summer' [45]. The Australian Bureau of Meteorology (BoM) weather station at Sydney Observatory Hill showed an average recorded temperature of $27.6^{\circ} \mathrm{C}$ for January, which was $1.8^{\circ} \mathrm{C}$ warmer than the historical average for this location in this month. This was a result of prolonged and widespread extreme heat periods that affected most parts of Australia during January 2013 so that higher temperatures were recorded across the whole southeast of Australia. Figure 3 shows maps of simulated sea-level pressure (SLP) and 2-m temperature from 7 January to 18 January 2013 at 3:00 p.m. local time. Generally, the simulated synoptic pattern shows a high pressure system over eastern Australia for the whole duration of the model run. This high pressure system, combined with hot northerly winds, caused the extreme temperatures that were observed on 8 January, 12 January and 18 January. Figure $4 a$ shows a time-series of mean observed and simulated temperature averaged over all 17 measurement sites. The observed time-series of mean temperature is captured well by the model with a correlation coefficient of 0.9 , a mean bias (MB) of $0.2^{\circ} \mathrm{C}$ and a normalised mean bias (NMB) of $0.8 \%$. In general, as a mean across the 17 sites, the simulated temperatures are very similar (to within $1-3^{\circ} \mathrm{C}$ ) to the measured temperatures, with the exception of the night of the 12th of January when the model is much warmer $\left(27^{\circ} \mathrm{C}\right)$ than observed $\left(20^{\circ} \mathrm{C}\right)$.

In order to analyse model skill at simulating observed wind speeds, we used data from the BoM observation network because these are better located or sited (i.e., not sheltered) than the OEH sites (for which we found consistent underestimation for wind speeds compared to the BoM data). Across these eight sites, the observed mean wind speeds range from $1.5 \mathrm{~m} \cdot \mathrm{s}^{-1}$ at night to a maximum of $7-10 \mathrm{~m} \cdot \mathrm{s}^{-1}$ during the day, representing moderate wind speeds during the extreme heat periods. Not only does the model capture the magnitude of observed wind speed very well with correlation coefficient of 1.0, slope of $0.8, \mathrm{MB}$ of $0.2 \mathrm{~m} \cdot \mathrm{s}^{-1}$ and NMB of $3.9 \%$ (see Figure $4 \mathrm{~b}$ ), but it also tracks the measured wind direction (Figure 4c) with correlation coefficient of 0.8 , slope of $0.8, \mathrm{MB}$ of $-5.7^{\circ}$ and $\mathrm{NMB}$ of $-3.8 \%$. As is usually expected, the extreme heat periods were associated with winds from the warmer north or northeast interior. A time-series of measured (calculated from vertical meteorological soundings of the atmosphere using the method described in Seidel et al. [46]) and simulated PBL heights (diagnosed by both the Yonsei University (YSU) and the Mellor-Yamada-Janjic (MYJ) PBL schemes) from Sydney airport (see Figure 4d) shows that the PBL heights are deeper during 8 January and 18 January—extreme heat days. Both PBL schemes correctly predict deep PBL height for 8 January, but only the MYJ scheme predicts the deep PBL height observed on 18 January. Extreme PBL heights exceeding $4 \mathrm{~km}$ are reminiscent of those that were observed during the extreme heat events that led to the 2009 Black Saturday fires in Victoria [47]. Across the region, a map of simulated PBL heights is shown in Figure 5 for each of the days from 7 to 18 January 2013 at 3:00 p.m. local time. Clearly, the extremely warm days have a deeper mixed layer over land due to convection from the extreme heat, and a shallower PBL height over the Pacific Ocean to the east of Sydney. On the hot days, the region is characterised by offshore flow, which means that warm air from the land is travelling over the cooler ocean surface. The near-surface air is stable, which leads to a shallow PBL. For onshore flow, cool southerly air is travelling over warmer water (water further north is warmer) creating an unstable air mass (with air being heated from below) which leads to a deeper PBL. The model tracks the measured shortwave radiation (see Figure 4e) very well. Although there is a reduction in radiation during the non-heatwave days as expected, there is no significant variation in simulated and measured radiation from one extreme heat event to another.

A companion paper [48] provides more in-depth analysis of model comparison with meteorology. 


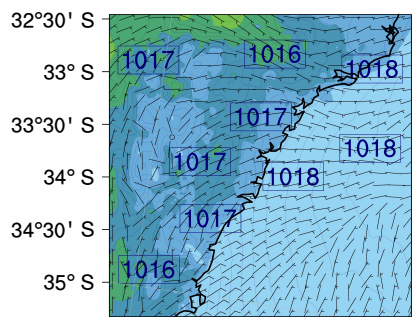

(a) 7 Jan 2013

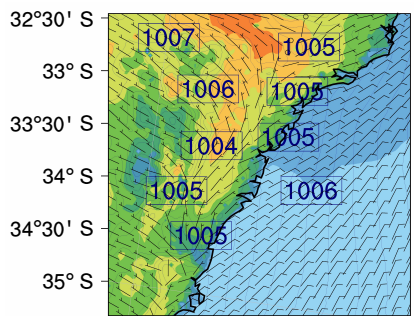

(e) 11 Jan 2013

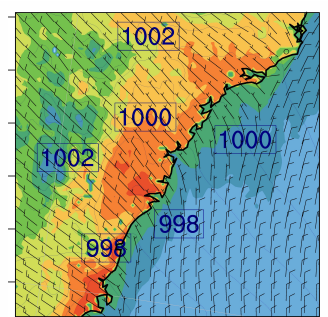

(b) 8 Jan 2013

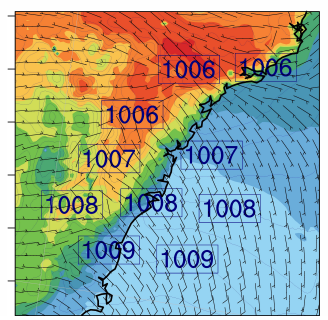

(f) 12 Jan 2013

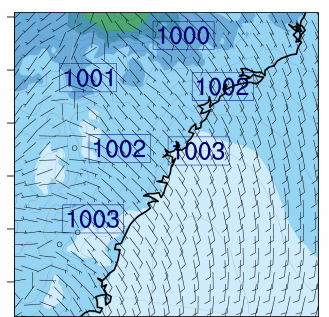

(c) 9 Jan 2013

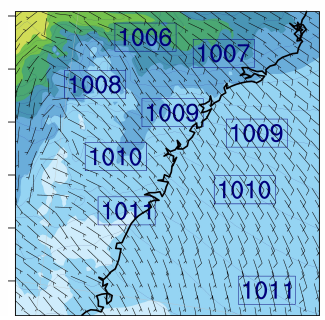

(g) 13 Jan 2013

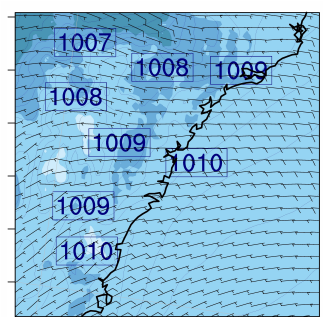

(d) 10 Jan 2013

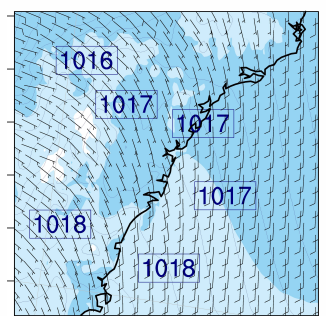

(h) 14 Jan 2013
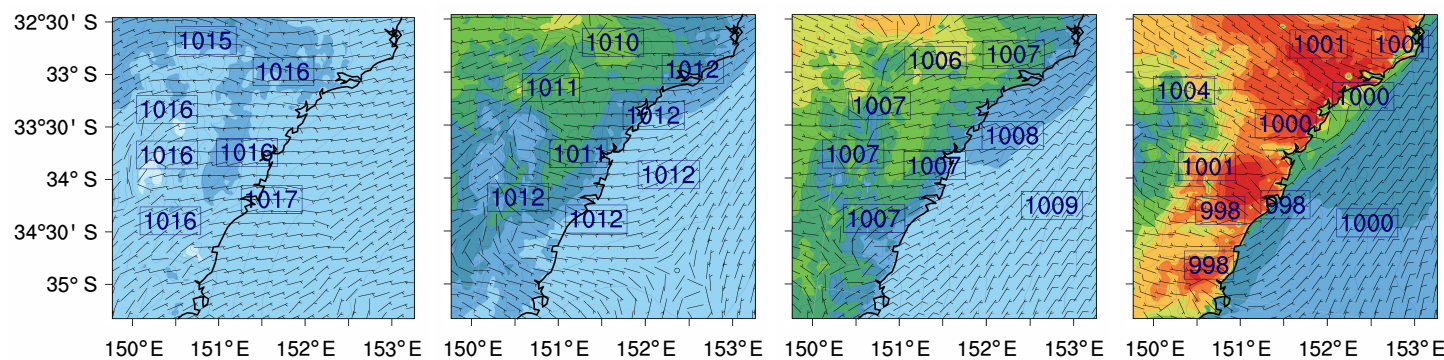

(i) 15 Jan 2013

(j) 16 Jan 2013

(k) 17 Jan 2013

(l) 18 Jan 2013

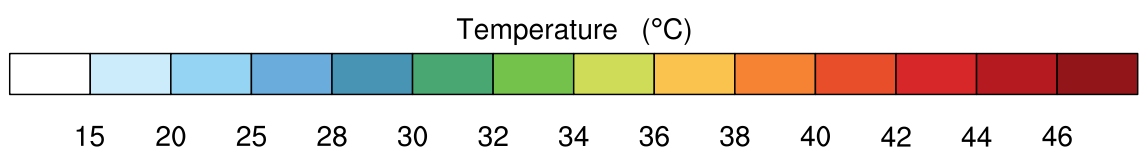

Figure 3. Simulated temperature and sea-level pressure (hPa) from 7 January to 18 January 2013 at 3:00 p.m. local time.

\subsection{Simulation of Observed Surface Trace Gases}

Figure 6 presents a timeseries of simulated and observed ozone and $\mathrm{NO}_{x}$ mixing ratios averaged over 17 sites across Greater Sydney. Isoprene and formaldehyde were measured at only one site and thus are not shown here but are shown later in Section 3.3.1. Across the 17 sites, the model generally captures the observed surface ozone mixing ratio but seems to underestimate the initial phase of the extreme heat period from 8 January to 11 January. For the extreme heat on 12th January, the model overestimates the observed mean peak mixing ratios of 50 ppbv by over $10 \mathrm{ppbv}$, but there is much closer agreement for the later extreme heat period on 18 January. Overall, the model simulates ozone with a slope of 0.8 , a Pearson correlation coefficient (R) of 0.8 and $\mathrm{MB}$ of -3 ppbv. $\mathrm{NO}_{x}$ is more impacted by local sources. Therefore, it is not surprising that, at a resolution of $3 \mathrm{~km} \times 3 \mathrm{~km}$, the model struggles with simulation of $\mathrm{NO}_{x}$ (slope $=0.4, \mathrm{R}=0.6 \mathrm{MB}=0.3 \mathrm{ppbv}$ and $\mathrm{NMB}=3.8 \%$ ). 


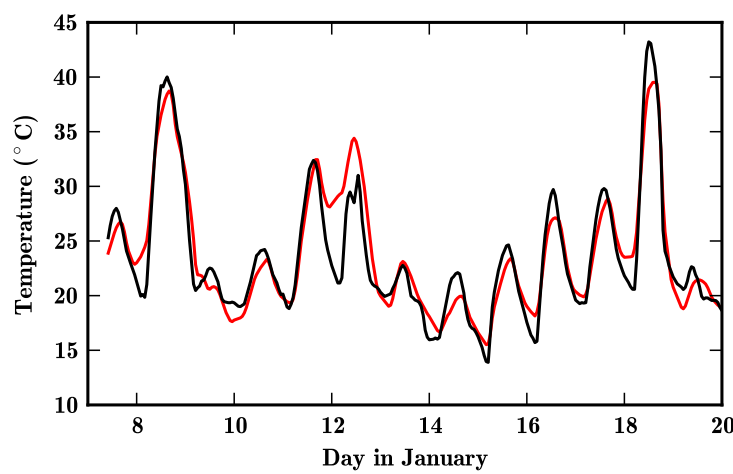

(a) Temperature

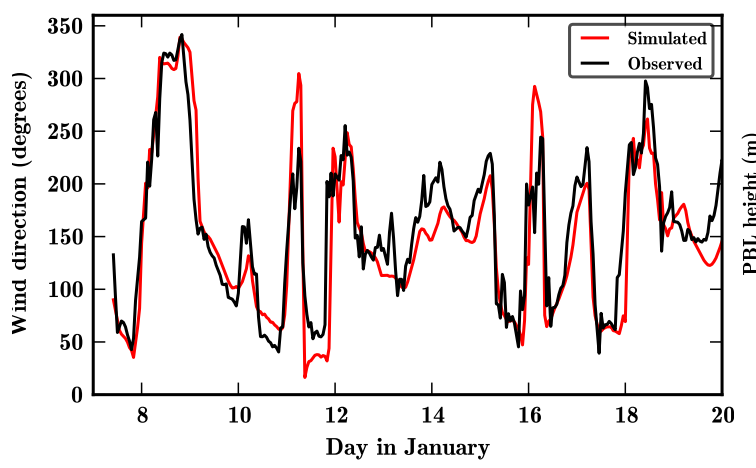

(c) Wind direction

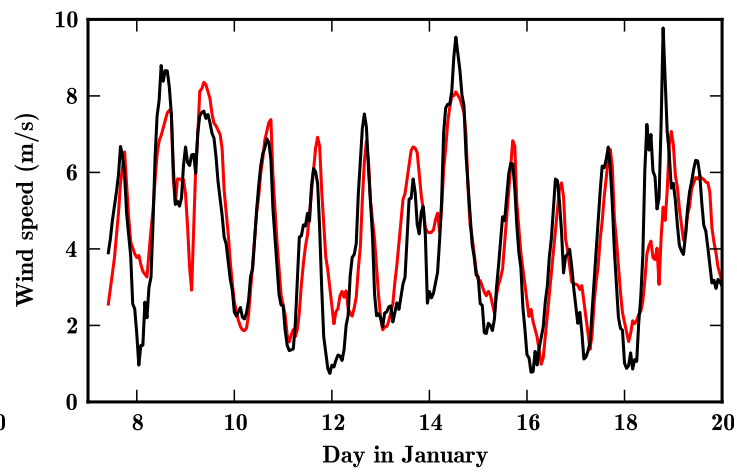

(b) Wind speed

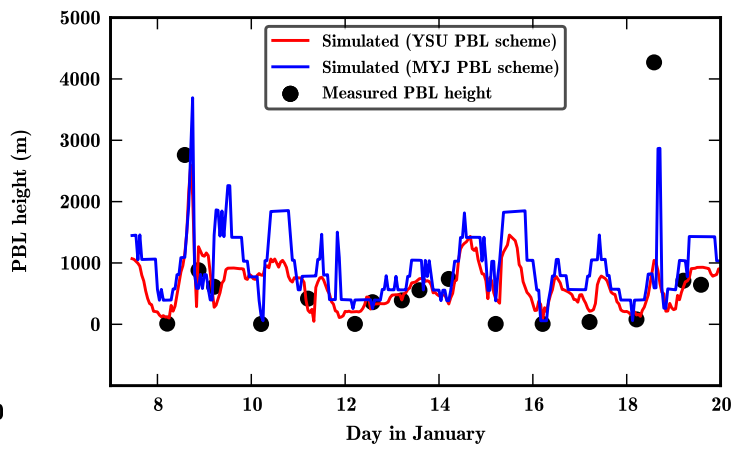

(d) PBL height

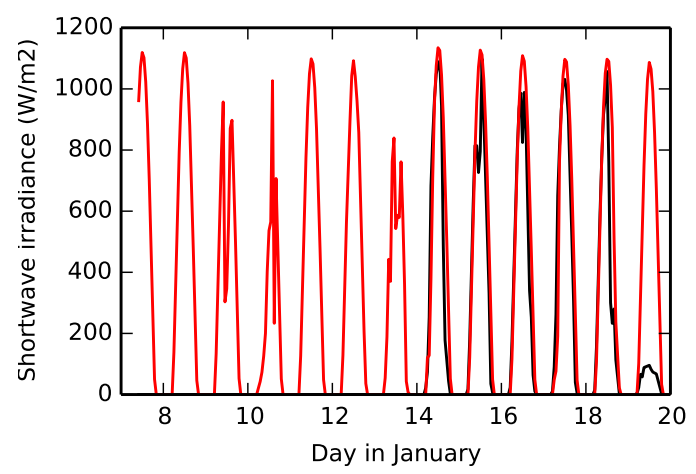

(e) Shortwave radiation

Figure 4. Observed (in black colour) and simulated (in red colour) meteorological variables, averaged over all measurement sites. For shortwave radiation, the data is provided for MUMBA site only.

The spatial distribution of simulated ozone mixing ratios from 7 January to 18 January 2013 at 3:00 p.m. local time is shown in Figure 7. Also plotted on these maps are wind vector fields showing wind speed and wind direction. Simulated ozone mixing ratios range from 10 to $120 \mathrm{ppbv}$ with background mixing ratios in the range of $10-40$ ppbv over large parts of the region (over land and the Pacific ocean). During the extreme heat episodes of 8 January, 12 January and 18 January, plumes of high ozone mixing ratios are advected offshore (Figure $7 \mathrm{~b}, \mathrm{f}, \mathrm{l}$ ) but over land the mixing ratios are lower (30-50 ppbv). The reduced mixing ratios over land are possibly due to a number of factors: higher wind speeds during the warm days combined with higher mixing layer height over land and the lack of ozone titration due to low $\mathrm{NO}_{x}$ and VOCs over the ocean. This is shown clearly during the cooler days when we see comparatively higher ozone further inland in areas (Figure 7j,k) which have lower PBL height (see Figure 5j,k). We also see that the simulated ozone plumes (Figure 7b) coincide with simulated isoprene dips (Figure 8). Various studies have shown strong gradients in ozone mixing ratios near forest canopies due to high fluxes of biogenic emissions (e.g., [49-51]). This negative ozone sensitivity to isoprene can occur through various pathways. For example, it can be caused by the direct 
reaction between ozone and isoprene or indirectly, under $\mathrm{NO}_{x}$-limited conditions, by reactions that remove $\mathrm{NO}_{x}$ to form organic nitrates [52]. However, more likely, the isoprene dips are caused by direct titration through the ozonolysis reaction, the products of which include formaldehyde and acetyl peroxy radicals. The latter reacts with NOx to form PAN. The isoprene dips coincide with increase in both formaldehyde (not shown here) as well as PAN (shown in Section 3.3).

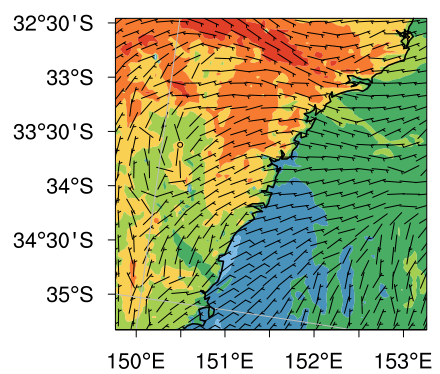

(a) 7 Jan 2013

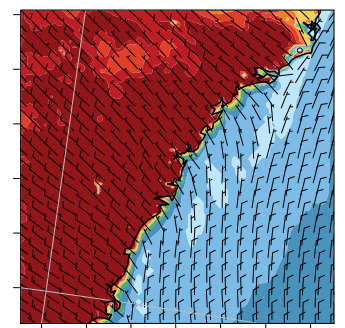

$150^{\circ} \mathrm{E} \quad 151^{\circ} \mathrm{E} \quad 152^{\circ} \mathrm{E} \quad 153^{\circ} \mathrm{E}$

(b) 8 Jan 2013

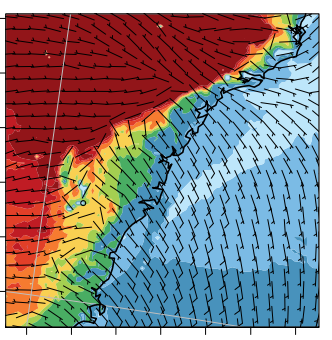

$150^{\circ} \mathrm{E} \quad 151^{\circ} \mathrm{E} \quad 152^{\circ} \mathrm{E} \quad 153^{\circ} \mathrm{E}$

(e) 11 Jan 2013

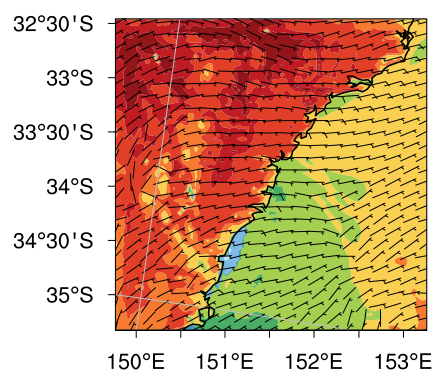

(i) 15 Jan 2013 (f) 12 Jan 2013

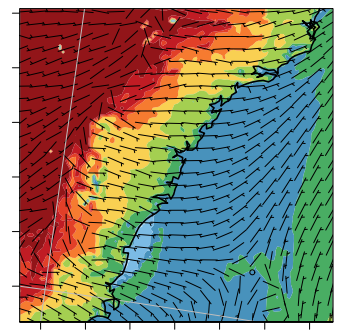

(j) 16 Jan 2013

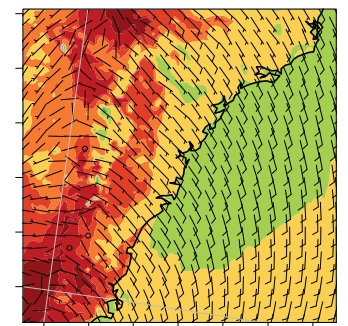

(c) 9 Jan 2013

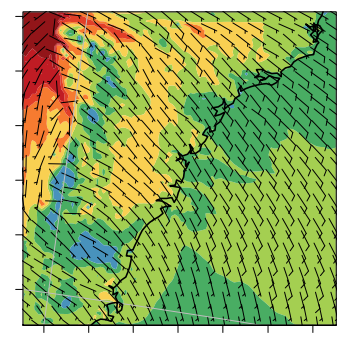

(g) 13 Jan 2013

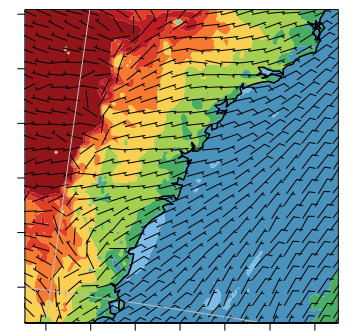

(k) 17 Jan 2013

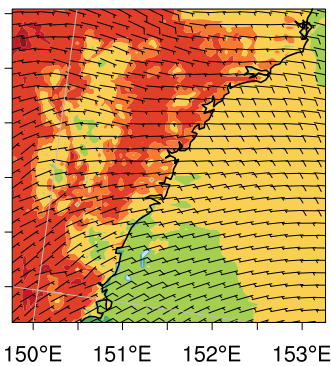

(d) 10 Jan 2013

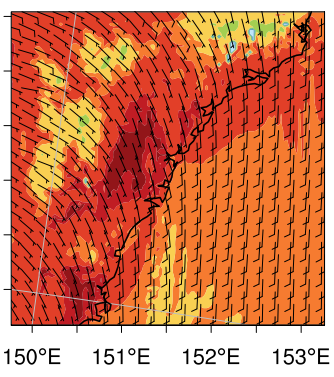

(h) 14 Jan 2013

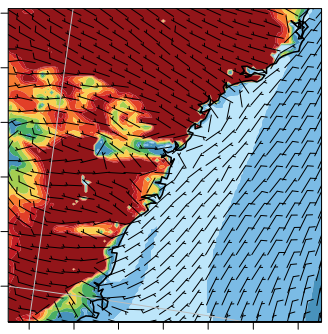

(l) 18 Jan 2013

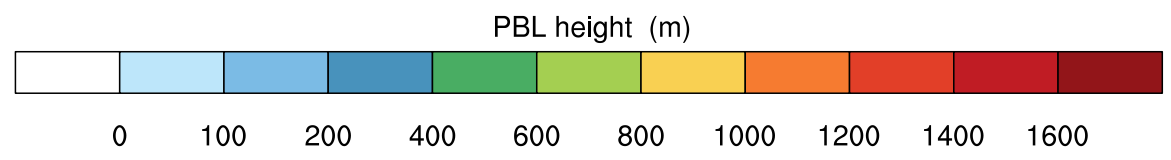

Figure 5. Map of simulated Planetary Boundary Layer (PBL) height (simulated by the Yonsei University (YSU) PBL scheme) from 7 January to 18 January 2013 at 3:00 p.m. local time.

The simulated surface isoprene maps (Figure 8) indicate that the model may be overestimating isoprene mixing ratios. However, it is worth noting that there are very few measurements of isoprene in Australia. The highest ever observed isoprene mixing ratio is about $7 \mathrm{ppbv}$ and these are normally measured in city locations and not close to the sources of isoprene. At the model resolution of $3 \mathrm{~km}$, the grid cell in which the measurement site is located includes the local forest so that the model will see higher isoprene mixing ratios which in reality will be titrated out by ozone by the time the isoprene gets to the measurement site. Our simulations (not shown in the paper) of isoprene in the $9 \mathrm{~km}$ and $3 \mathrm{~km}$ domains show that the latter simulates about $5 \mathrm{ppb}$ less isoprene than the 
former. A plot of hydroxyl radical $(\mathrm{OH})$ concentrations (Figure 9) shows $\mathrm{OH}$ concentrations in the range of $5 \times 10^{5}$ to $2.0 \times 10^{8}$ molecules $/ \mathrm{cm}^{3}$. As a comparison, $\mathrm{OH}$ measurements at Cape Grim are $3.5 \times 10^{6}$ molecules $/ \mathrm{cm}^{3}$ average maximum [53].

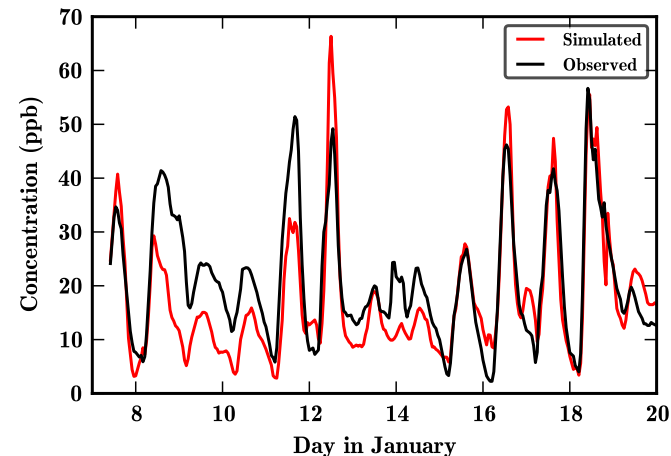

(a) $\mathrm{O}_{3}$

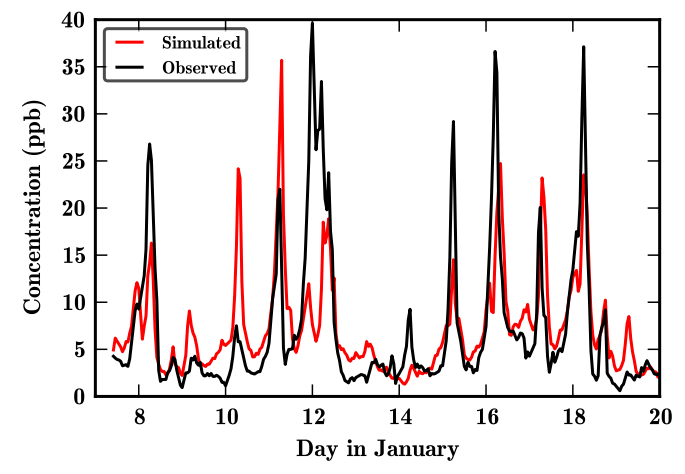

(b) $\mathrm{NO}_{x}$

Figure 6. Timeseries of measured and simulated surface ozone and $\mathrm{NO}_{x}$ averaged across 17 sites in Greater Sydney.

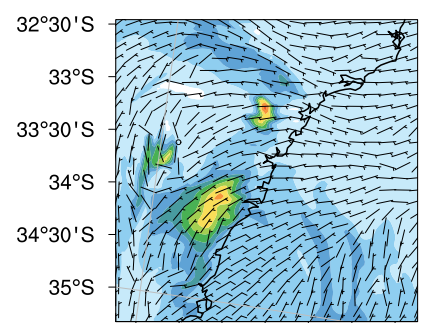

(a) 7 Jan 2013

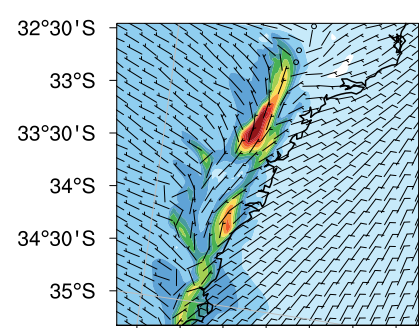

(e) 11 Jan 2013

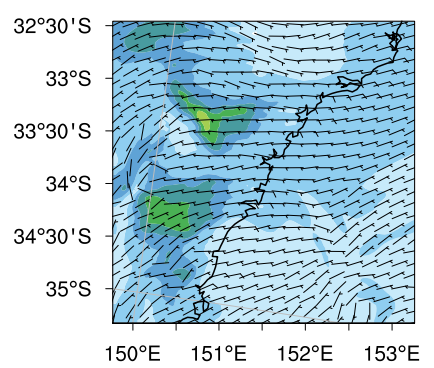

(i) 15 Jan 2013

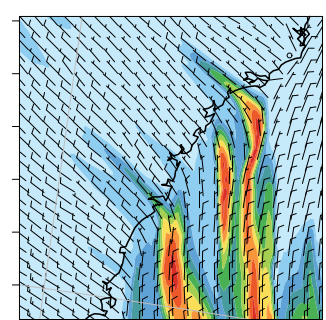

(b) 8 Jan 2013

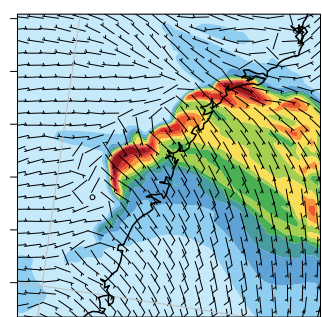

(f) 12 Jan 2013

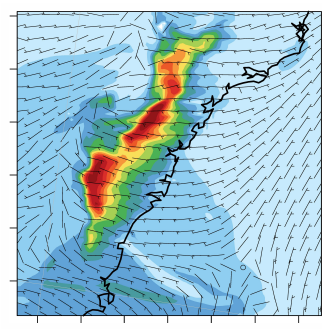

(j) 16 Jan 2013

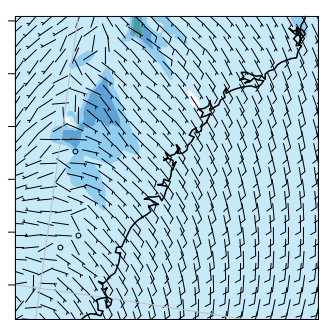

(c) 9 Jan 2013

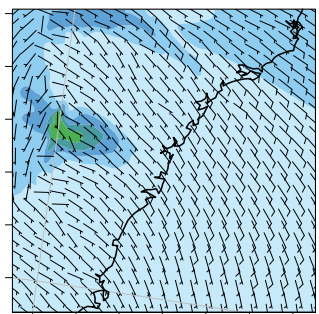

(g) 13 Jan 2013

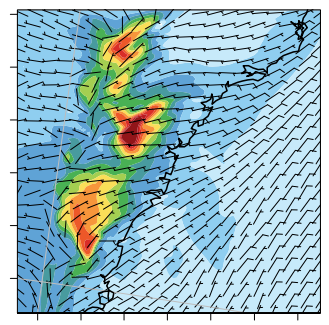

(k) 17 Jan 2013

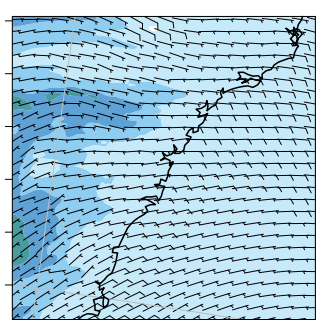

(d) 10 Jan 2013

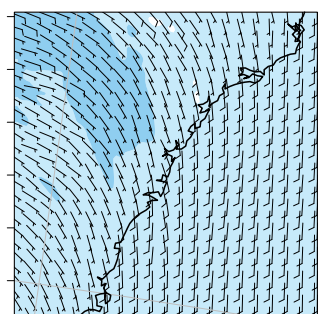

(h) 14 Jan 2013

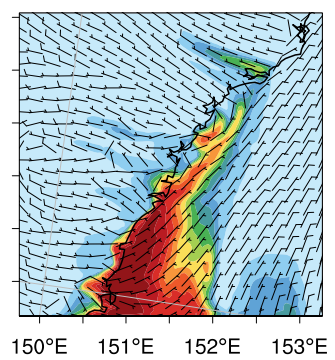

(l) 18 Jan 2013

Ozone mixing ratio (ppbv)

\begin{tabular}{l|l|l|l|l|l|l|l|l|l|l|l|l|} 
& & & & & & & & & & & & \\
10 & 20 & 30 & 40 & 50 & 60 & 70 & 80 & 90 & 100 & 110 & 120
\end{tabular}

Figure 7. Simulated surface $\mathrm{O}_{3}$ from 7 January to 18 January 2013 at 3:00 p.m. local time. 


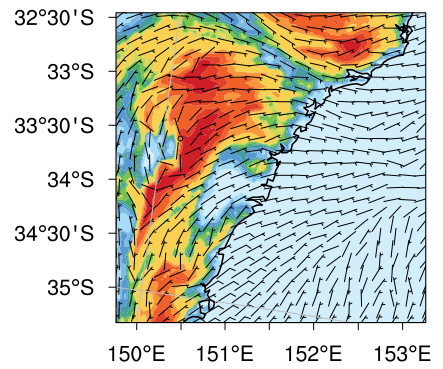

(a) 7 Jan 2013

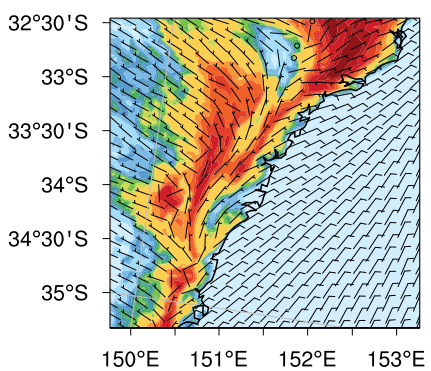

(e) 11 Jan 2013

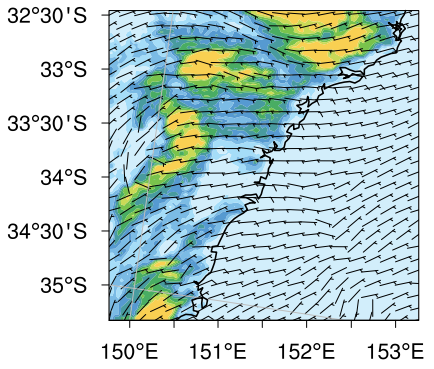

(i) 15 Jan 2013

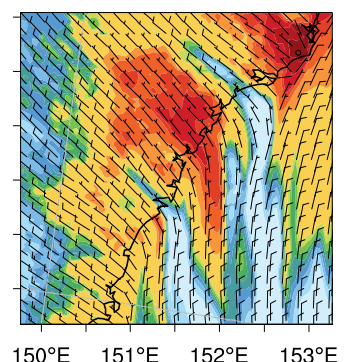

(b) 8 Jan 2013

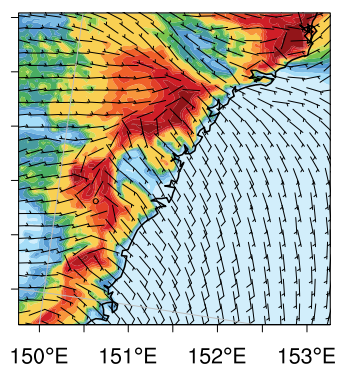

(f) 12 Jan 2013

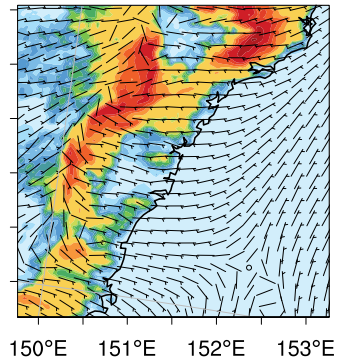

(j) 16 Jan 2013
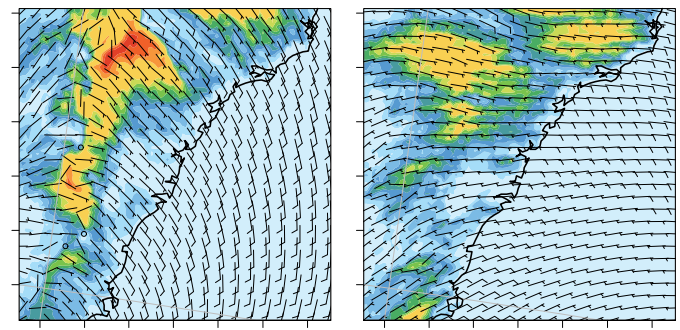

(c) 9 Jan 2013

(d) 10 Jan 2013

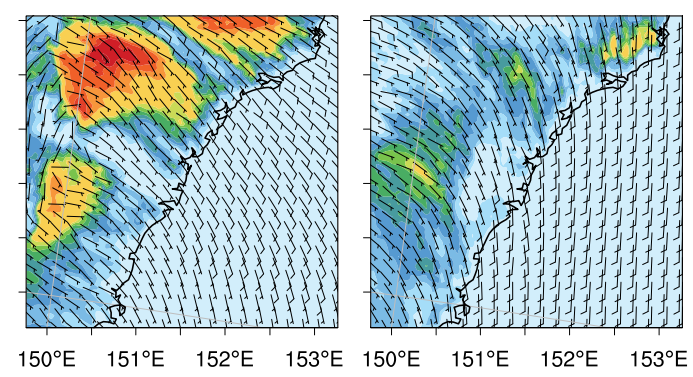

(g) 13 Jan 2013

(h) 14 Jan 2013

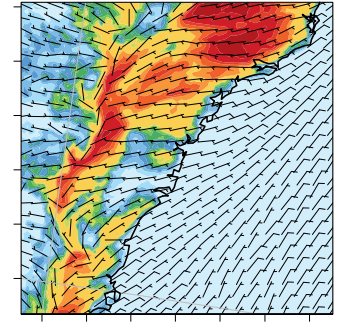

$150^{\circ} \mathrm{E} \quad 151^{\circ} \mathrm{E} \quad 152^{\circ} \mathrm{E} \quad 153^{\circ} \mathrm{E} \quad 150^{\circ} \mathrm{E} \quad 151^{\circ} \mathrm{E} \quad 152^{\circ} \mathrm{E} \quad 153^{\circ} \mathrm{E}$

(k) 17 Jan 2013

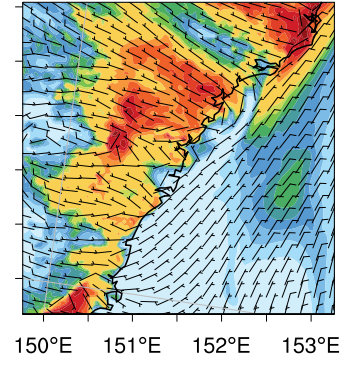

(l) 18 Jan 2013

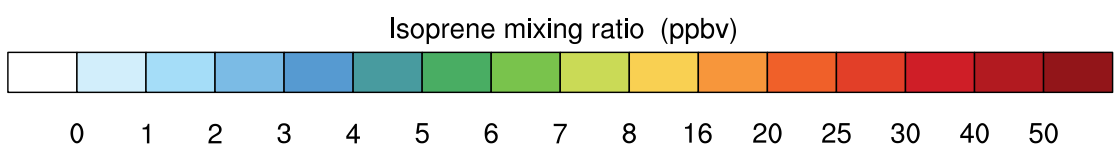

Figure 8. Simulated surface isoprene from 7 January to 18 January 2013 at 3:00 p.m. local time.

\subsection{Model Sensitivity Studies}

Although this study has not looked at the direct influence of meteorology (such as PBL depth and stagnation events) on the elevated pollutant mixing ratios during the extreme heat, it is worth noting that these too can lead to elevated pollutant mixing ratios. However, in this study, all model sensitivity studies used the same meteorology and PBL scheme, so we only address the contribution of biogenic emissions and chemistry to air pollution episodes.

Extreme temperatures and extreme biogenic emissions were simulated during the extreme heat period in Greater Sydney. Figure 10a,b show the simulated and monthly averaged temperature and isoprene emissions, respectively. As a mean across all 17 sites, we see that differences in temperatures between average and standard conditions were as high as $15^{\circ} \mathrm{C}$, which translates into isoprene emission differences of over $40 \mathrm{~mole} / \mathrm{km}^{2} / \mathrm{h}$. Maps of the difference between simulated standard and average temperature and isoprene emissions for 3:00 p.m. (local time) on 18 January are shown in Figure 11. The largest differences of up to $20^{\circ} \mathrm{C}$ are found close to the shoreline (and therefore close to the city), with differences decreasing towards high altitude in the mountainous western and northwestern part of the domain (see topographical map in Figure 1). The reasons for this spatial 
pattern are two-fold. Towards the mountains, the air is cooler and hence the difference from average temperature is smaller. Towards the cities, the urban heat island effect tends to exacerbate the intensity of heatwaves so that the difference from average conditions is more pronounced [54,55]. Even though the relatively cooler conditions in the Blue Mountains means lower isoprene emissions relative to the case under warmer conditions, the emissions of isoprene are still large since these areas are heavily vegetated. As shown in Figure 11b, the difference between standard and averaged isoprene emissions simulated in January 2013 ranges from -180 to $300 \mathrm{~mol} / \mathrm{km}_{2} / \mathrm{h}$ (shown for 18 January only).

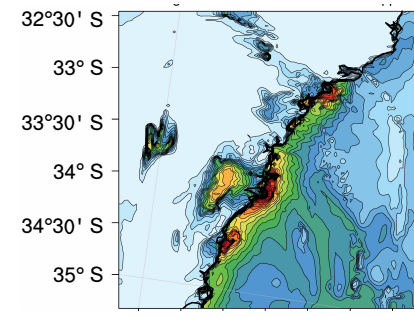

(a) 7 Jan 2013

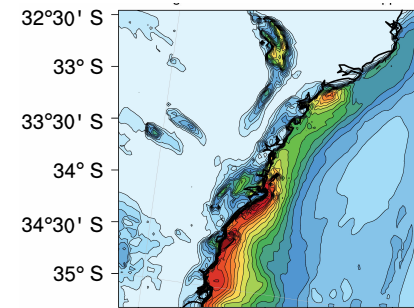

(e) 11 Jan 2013

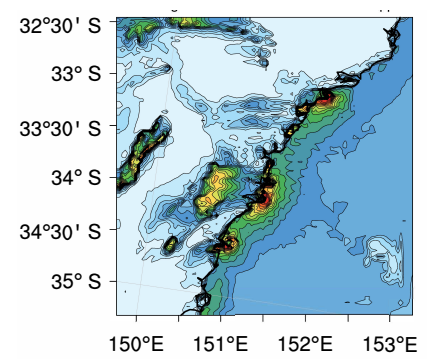

(i) 15 Jan 2013

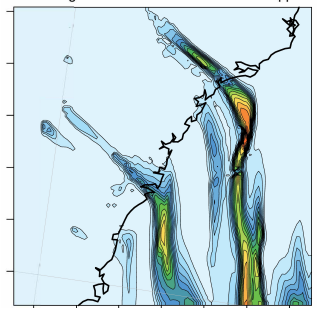

(b) 8 Jan 2013

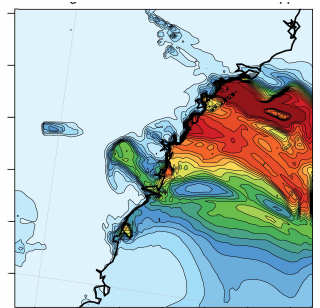

(f) 12 Jan 2013

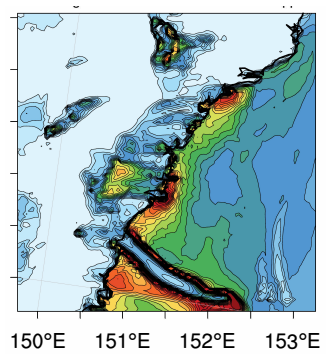

(j) 16 Jan 2013

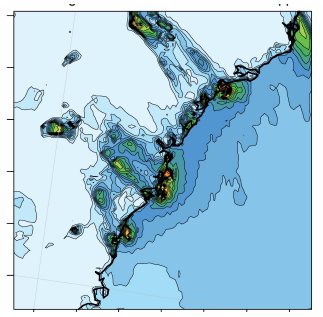

(c) 9 Jan 2013

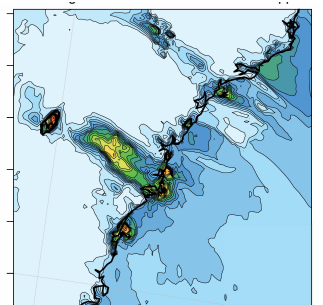

(g) 13 Jan 2013

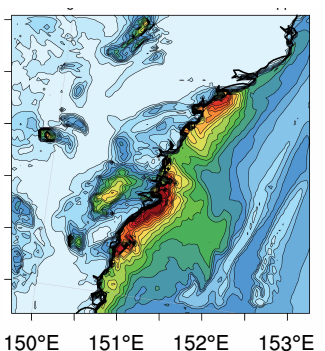

(k) 17 Jan 2013

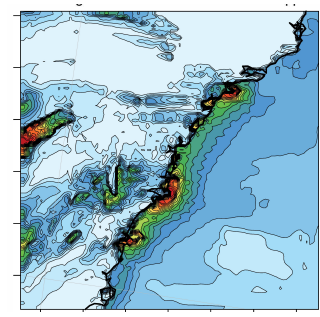

(d) 10 Jan 2013

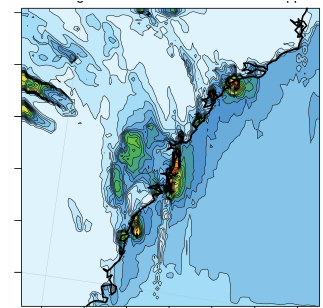

(h) 14 Jan 2013

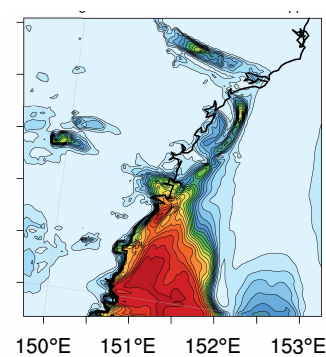

(l) 18 Jan 2013

$\mathrm{OH}$ concentration (molecules $/ \mathrm{cm}^{3}$ )

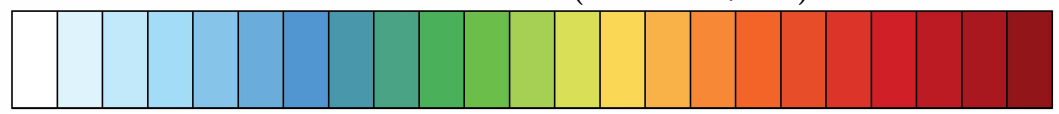

\section{$\begin{array}{lllll}1.0 \mathrm{E}+05 & 5.0 \mathrm{E}+07 \quad 1.0 \mathrm{E}+08 \quad 1.5 \mathrm{E}+08 \quad 2.0 \mathrm{E}+08\end{array}$}

Figure 9. Simulated surface hydroxyl $(\mathrm{OH})$ radical concentrations from 7 January to 18 January 2013 at 3:00 p.m. local time.

Figure 12 shows a time-series plot of the mean ozone mixing ratios from all 17 sites simulated with standard model conditions (scenario STD_ET) as well as simulated with the various sensitivity studies: with biogenic emissions averaged from January standard emissions (scenario AVG_E), with temperatures averaged from January standard temperatures (scenario AVG_T) and with both temperature and emissions averaged (scenario AVG_ET). As expected, the largest ozone differences are seen during the warm periods (8 January, 12 January and 18 January 2013) when the differences between standard and averaged conditions (for both temperature and emissions) are at their highest. Zooming in on the extreme heat days on 12 January and 18 January (see Figure 13a,b), we see that the runs with 
averaged biogenic emissions (but standard temperatures) and averaged temperatures (but standard biogenic emissions) give similar ozone responses, with simulated mean ozone mixing ratios reduced by about $5 \mathrm{ppbv}$ from the standard run. As expected, the run in which both the biogenic emissions and temperatures are averaged gives the largest ozone difference but, interestingly, this difference is approximately equal to the sum of differences from the separate runs in which only temperature or only emissions are averaged (i.e., STD_ET-AVG_ET $=($ STD_ET-AVG_E) + $($ STD_ET-AVG_T) $)$. Tables 3 and 4 show the hourly ozone differences between 6:00 a.m. and 5:00 p.m. on 12 January and 18 January 2013, respectively. On average (from 6:00 a.m. to 5:00 p.m.), we find reductions in ozone mixing ratios from the standard simulation of 3.8 and 3.2 ppbv for runs from AVG_E and AVG_T, respectively, on the 12 January, and 5.8 and 5.3 ppbv for AVG_E and AVG_T runs on 18 January. For AVG_ET runs, we find a reduction of 6.5 and $10 \mathrm{ppbv}$ (relative to the standard run) on 12 January and 18 January, respectively. That the effect of temperature is as large as that of biogenic emissions is perhaps surprising, but it should be noted that on these extremely hot days the difference between simulated standard and average temperature was large (mean difference of 10 and $14{ }^{\circ} \mathrm{C}$ across all 17 sites on 12 January and 18 January, respectively). It should also be noted that in these model runs we have ignored implicitly the effect of temperature change on humidity, which will affect the $\mathrm{OH}$ concentrations and, therefore, photochemistry.

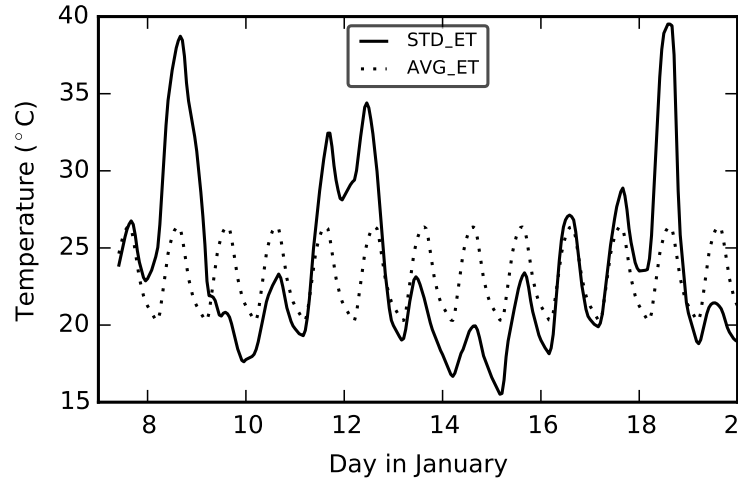

(a) Standard and average temperature

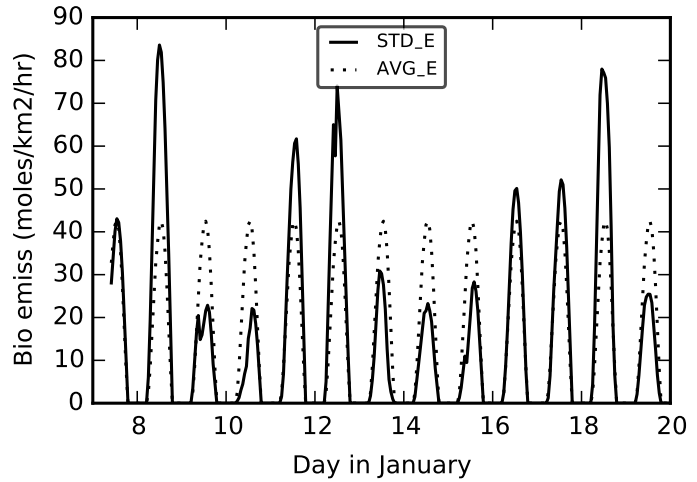

(b) Standard and average isoprene emissions

Figure 10. Standard and monthly averaged temperature and isoprene emissions.

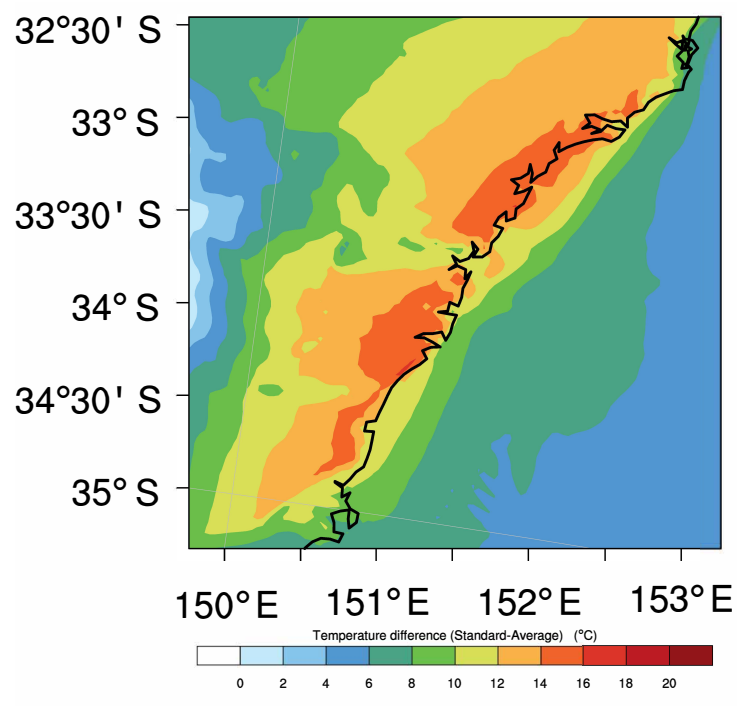

(a) Temperature difference map

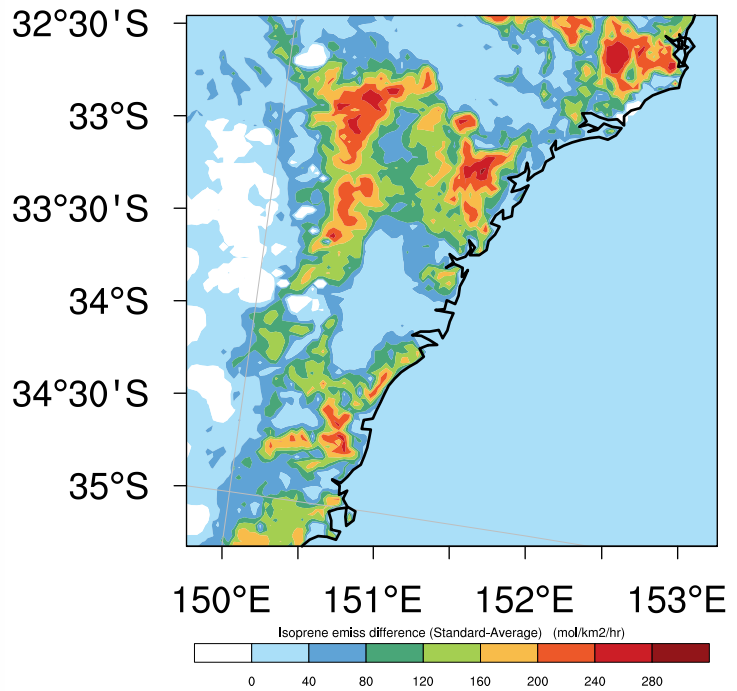

(b) Isoprene emissions difference map

Figure 11. Maps of difference between standard and average temperature (STD_T-AVG_T) and isoprene emissions (STD_E-AVG_E) at 3:00 p.m. on 18 January 2013. 


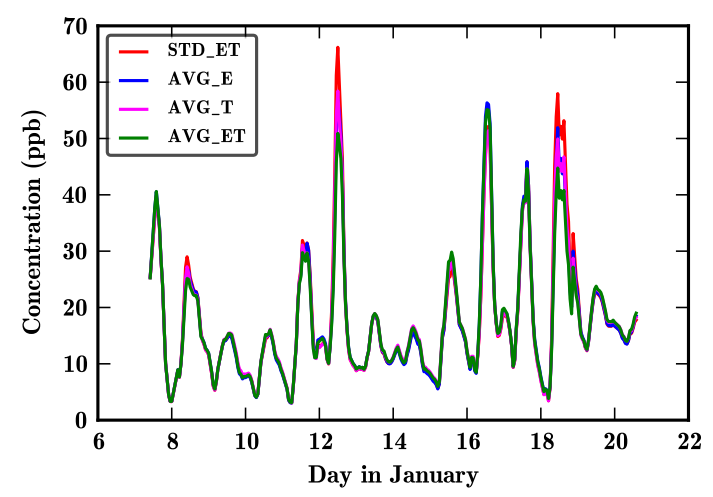

Figure 12. Timeseries of simulated $\mathrm{O}_{3}$ from the 17 sites for various scenarios from 7 to 20 January 2013.

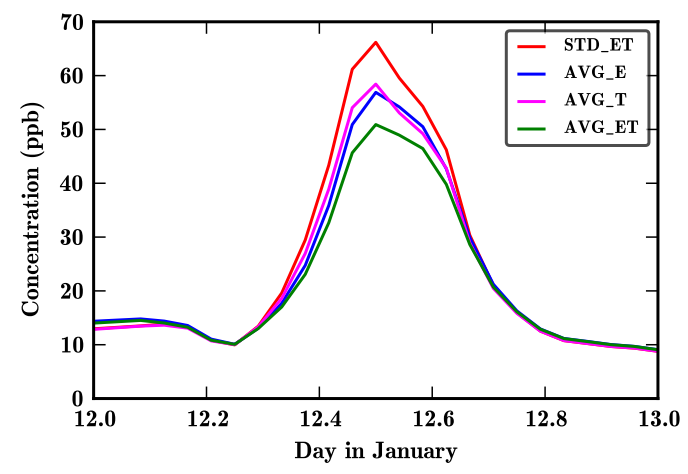

(a) 12th January

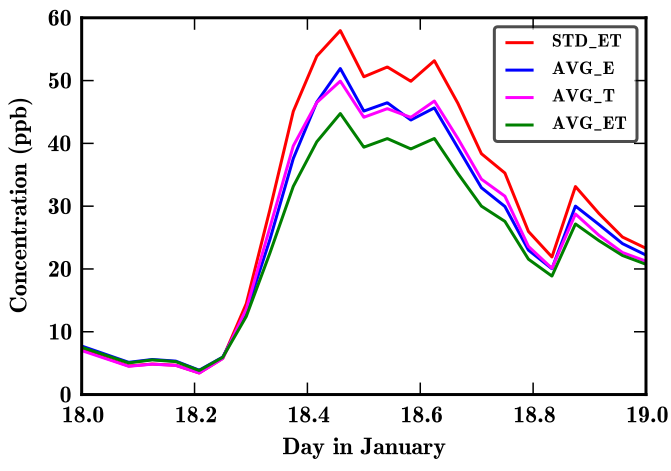

(b) 18th January

Figure 13. Timeseries of simulated $\mathrm{O}_{3}$ from the 17 sites for various scenarios on 18 January 2013.

Table 3. Table showing differences in ozone (ppbv) for 12 January between 6:00 a.m. and 5:00 p.m. for various scenarios where STD_ET is the run under standard or normal biogenic emissions and temperatures, AVG_E is the run with averaged biogenic emissions, AVG_T is the run with averaged temperatures and AVG_ET is the run with both averaged biogenic emissions and temperatures.

\begin{tabular}{cccc}
\hline Hour & STD_ET-AVG_E (ppbv) & STD_ET-AVG_T (ppbv) & STD_ET-AVG_ET (ppbv) \\
\hline 6.0 & -0.0 & 0.0 & 0.0 \\
7.0 & 0.0 & 0.0 & 1.0 \\
8.0 & 2.0 & 1.0 & 3.0 \\
9.0 & 5.0 & 2.0 & 6.0 \\
10.0 & 7.0 & 4.0 & 10.0 \\
11.0 & 10.0 & 7.0 & 15.0 \\
12.0 & 9.0 & 8.0 & 15.0 \\
13.0 & 5.0 & 7.0 & 11.0 \\
14.0 & 3.0 & 5.0 & 8.0 \\
15.0 & 4.0 & 4.0 & 7.0 \\
16.0 & 1.0 & 2.0 & 3.0 \\
17.0 & 0.0 & 1.0 & 1.0 \\
\hline Mean & 4.0 & 3.4 & 6.6 \\
\hline
\end{tabular}

In the results presented above, we have assumed that there is no significant change in photolysis rates from aerosol-radiation feedback during the simulation period. As noted earlier in the introduction, the absorption and scattering of radiation by aerosols can affect radiation flux, which, in turn, affects photolysis rates. We have seen in Section 3.1 that the simulated shortwave radiation during the extreme heat periods was largely similar. In order to assess the impact of aerosol-radiation feedback, we conducted further studies in which the model was run with aerosol-radiation feedback switched on. Table 5 shows the simulated differences in average ozone (ppbv) between 6:00 a.m. and 5:00 p.m. for various scenarios for A (STD_ET-AVG_E), B (STD_ET-AVG_T) and C (STD_ET-AVG_ET) for runs 
with and without aerosol radiation feedback. Also shown is the mean simulated ozone for STD_ET run (D). The differences between runs with feedback and without feedback are on average $0.2 \mathrm{ppbv}$. This confirms that there is no significant change in photolysis rates resulting from aerosol-radiation feedback during the extreme heat period.

Table 4. Table showing differences in ozone (ppbv) for 18 January between 6:00 a.m. and 5:00 p.m. for various scenarios where STD_ET is the run under standard or normal biogenic emissions and temperatures, AVG_E is the run with averaged biogenic emissions, AVG_T is the run with averaged temperatures and AVG_ET is the run with both averaged biogenic emissions and temperatures.

\begin{tabular}{cccc}
\hline Hour & STD_ET-AVG_E (ppbv) & STD_ET-AVG_T (ppbv) & STD_ET-AVG_ET (ppbv) \\
\hline 6.0 & 0.0 & 0.0 & 0.0 \\
7.0 & 1.0 & 1.0 & 2.0 \\
8.0 & 5.0 & 3.0 & 7.0 \\
9.0 & 7.0 & 5.0 & 12.0 \\
10.0 & 7.0 & 8.0 & 14.0 \\
11.0 & 6.0 & 8.0 & 14.0 \\
12.0 & 6.0 & 7.0 & 12.0 \\
13.0 & 6.0 & 7.0 & 12.0 \\
14.0 & 6.0 & 6.0 & 10.0 \\
15.0 & 7.0 & 6.0 & 12.0 \\
16.0 & 7.0 & 6.0 & 11.0 \\
17.0 & 6.0 & 4.0 & 9.0 \\
\hline Mean & 5.3 & 5.1 & 9.4 \\
\hline
\end{tabular}

Table 5. Table showing differences in average ozone (ppbv) between 6:00 a.m. and 5:00 p.m. for various scenarios for A (STD_ET-AVG_E), B (STD_ET-AVG_T) and C (STD_ET-AVG_ET). For runs with and without aerosol radiation feedback. Also shown is the mean absolute ozone for STD_ET run (D).

\begin{tabular}{cccccc}
\hline Date & Feedback & A (ppbv) & B (ppbv) & $\mathbf{C}(\mathbf{p p b v )}$ & $\mathbf{D}$ (ppbv) \\
\hline 08 January & No & 0.7 & 1.0 & 1.7 & 22.4 \\
12 January & No & 4.0 & 3.4 & 6.6 & 35.2 \\
18 January & No & 5.3 & 5.1 & 9.4 & 36.7 \\
\hline 08 January & Yes & 0.6 & 1.9 & 1.5 & 22.1 \\
12 January & Yes & 4.0 & 3.4 & 6.7 & 35.6 \\
18 January & Yes & 5.7 & 3.2 & 8.7 & 37.2 \\
\hline
\end{tabular}

Figure 14 shows simulated differences in ozone between the standard run and each of the three scenarios (i.e., AVG_T, AVG_E and AVG_ET) on the three extreme heat days on 8 January, 12 January, and 18 January 2013. The maps show ozone plumes being advected from land to the Pacific ocean with the largest difference in ozone for the STD_ET-AVG_ET run. Although the spatial structures for the STD_ET-AVG_T and STD_ET-AVG_E runs are very similar, there are some salient differences. For example, on 8 January, running the model with average isoprene emissions results in more ozone (i.e., STD_ET-AVG_E $\mathrm{O}_{3}$ is negative up to -2 ppbv) over parts of the land, whereas, for STD_ET-AVG_T, we see a positive difference of $0-2 \mathrm{ppbv}$ over large parts of the land. This suggests that over land areas conditions are mostly $\mathrm{NO}_{x}$-limited such that running the model with more isoprene removes $\mathrm{NO}_{x}$, which results in less ozone production over land. We also see isolated positive ozone difference 'plumes' (i.e., less simulated ozone in average scenarios than for the standard scenario) over land, presumably from $\mathrm{NO}_{x}$ sources. The advected ozone difference (positive) plumes are more pronounced (i.e., more ozone in the standard case than in the sensitivity scenario) over the ocean where there is less isoprene (due to its short lifetime). 

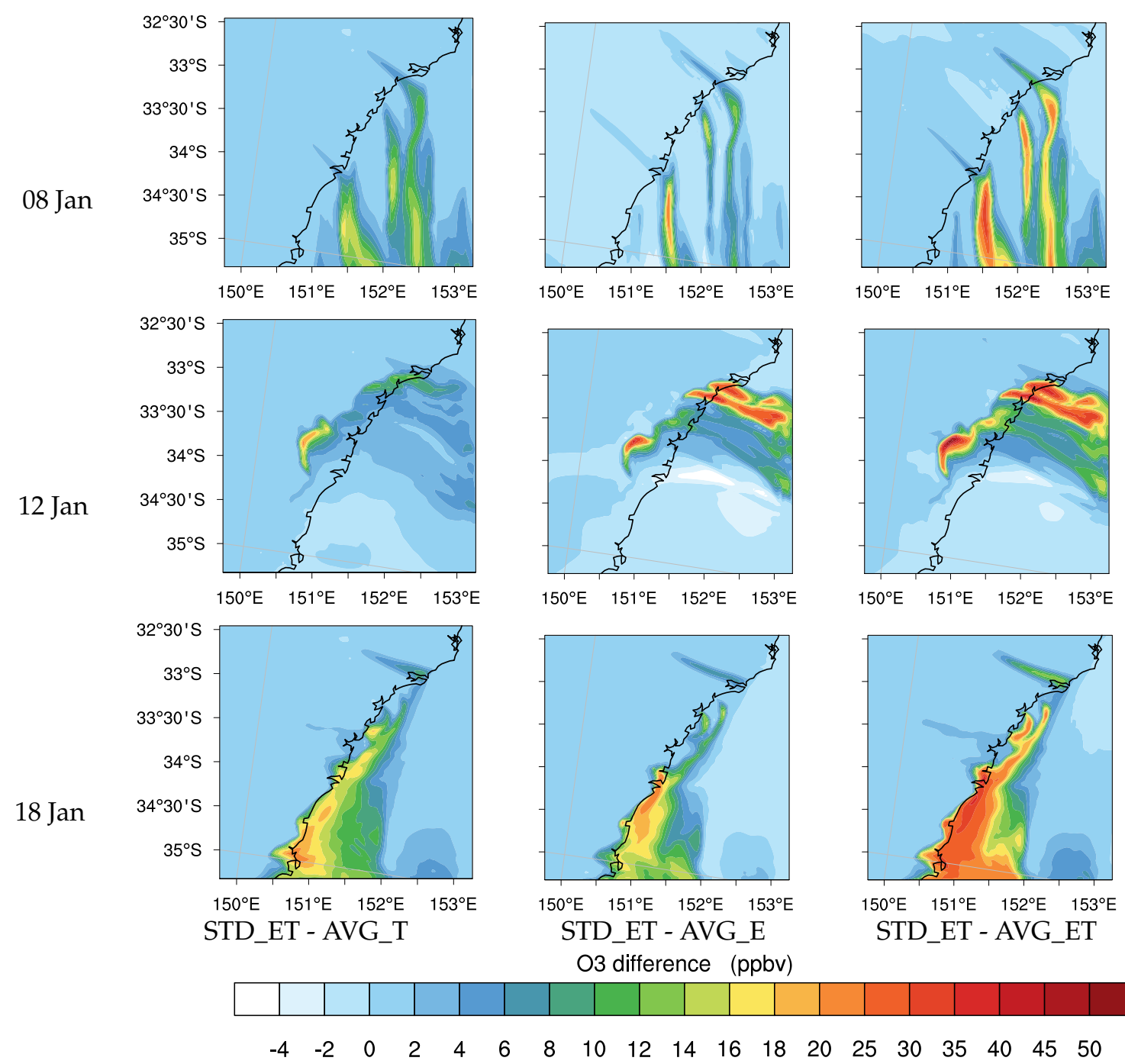

Figure 14. Difference in ozone between standard run and scenario runs during extreme heat days at 3:00 p.m. local time.

Due to the interconversion between $\mathrm{O}_{3}$ and $\mathrm{NO}_{2}$, it is instructive to consider a more conserved marker of photochemical production than $\mathrm{O}_{3}$. Following the works of e.g., Levy et al. [56] and Chou et al. [57], we define total oxidant $\left(\mathrm{O}_{x}\right)$ as:

$$
\mathrm{O}_{x}=\mathrm{O}_{3}+\mathrm{NO}_{2}+1.5 \mathrm{NO}_{z}
$$

where $\mathrm{NO}_{z}=\mathrm{NO}_{y}-\mathrm{NO}_{x}$ i.e., all the total reactive odd nitrogen less $\mathrm{NO}_{x}$. Differences in $\mathrm{O}_{x}$ between STD_ET and AVG_T and between STD_ET and AVG_E runs are shown in Figures 15 and 16, respectively. The magnitudes in $\mathrm{O}_{x}$ differences are similar for the two sets of experiments, although larger for STD_ET-AVG_E, again signifying the importance of biogenic emissions to their contribution to total oxidant.

The reduction in ozone at the lower temperatures can be attributed to a number of factors, including the reduced photolysis rates at lower temperatures, the altered reaction rates for various photochemical reactions (which increase or decrease depending on the sign of the pre-exponential Arrhenius factor, whether endothermic or exothermic), and the reduced water vapour mixing ratio at lower temperatures. In the work of Sillman and Samson [13] in which they studied the effect of temperature on ozone production, it was found that the change in reaction rates for the majority 
of the reactions did not impact the simulated ozone mixing ratio as much as the impact of reduced decomposition of PAN at lower temperatures. PAN is well known to represent a major sink for $\mathrm{NO}_{x}$, especially in rural environments where $\mathrm{NO}_{x}$ is limited. Figure 17 shows the difference in simulated PAN mixing ratios between the standard run and the average temperature run (STD_ET-AVG_T) for the three extreme heat days on 8 January, 12 January and 18 January 2013. As expected, the change in PAN is negative (up to $-2.8 \mathrm{ppbv}$ ) so that there is more PAN at the lower (average) temperature than under normal (standard) temperature. The loss in PAN at the higher standard temperature (compared to average temperature) results in more ozone. An analogous plot is also shown in Figure 18, this time showing the difference in PAN between the standard run and the averaged emissions run (STD_ET-AVG_E). In this case, there is higher PAN in the standard run than in the averaged emissions run. In both cases, the differences in simulated PAN concentrations tracks the differences in simulated ozone perfectly on the map, thus underlying the importance of PAN in regulating ozone mixing ratios downwind of precursors [58].

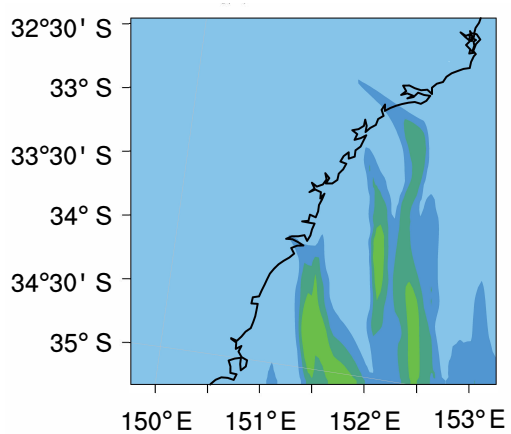

(a) 8 Jan 2013

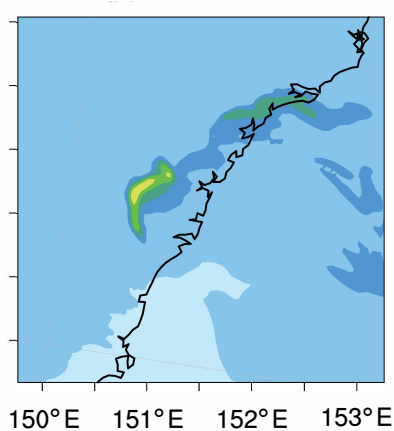

(b) 12 Jan 2013

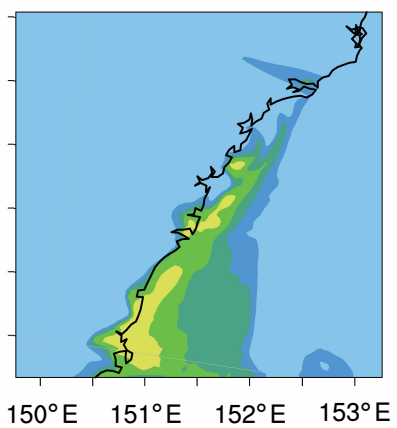

(c) 18 Jan 2013

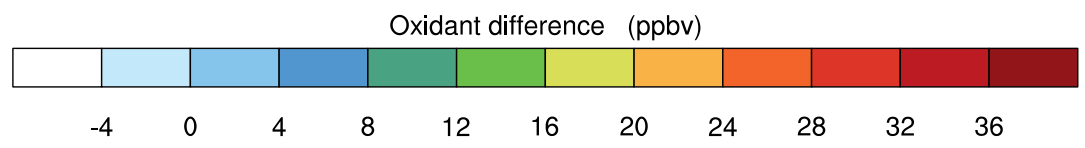

Figure 15. Simulated difference between $\mathrm{O}_{x}$ from standard run and $\mathrm{O}_{x}$ from average temperature run (STD_ET-AVG_T).

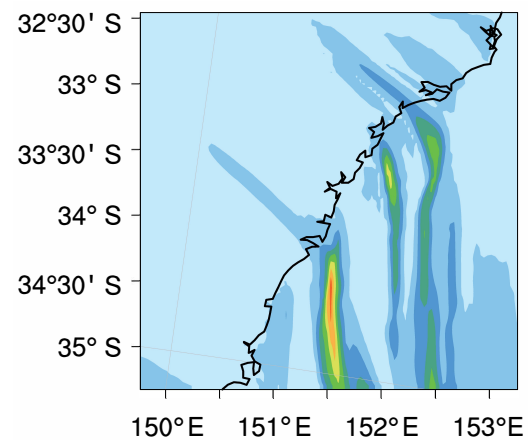

(a) 8 Jan 2013

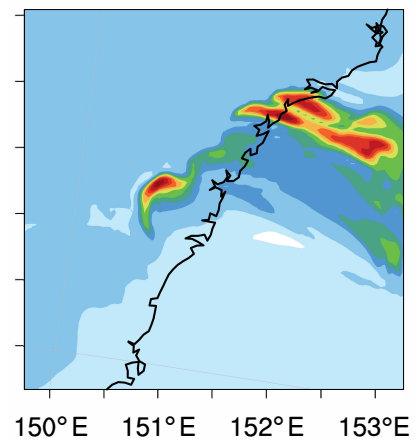

(b) 12 Jan 2013

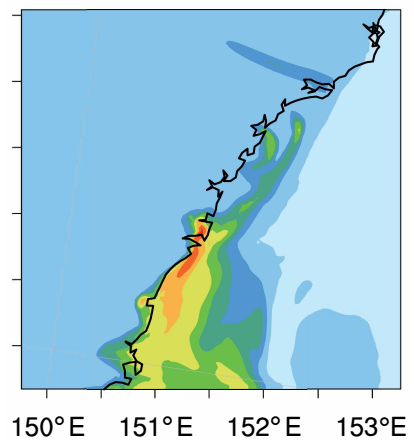

(c) 18 Jan 2013

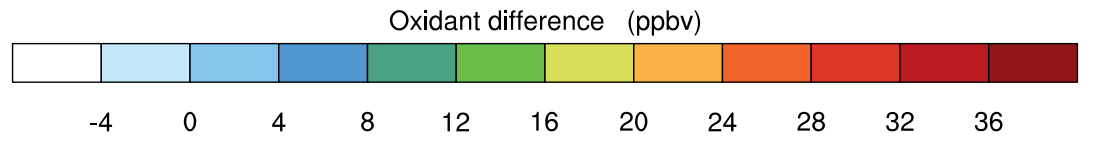

Figure 16. Simulated difference between $\mathrm{O}_{x}$ from standard run and $\mathrm{O}_{x}$ from average emissions run (STD_ET-AVG_E). 


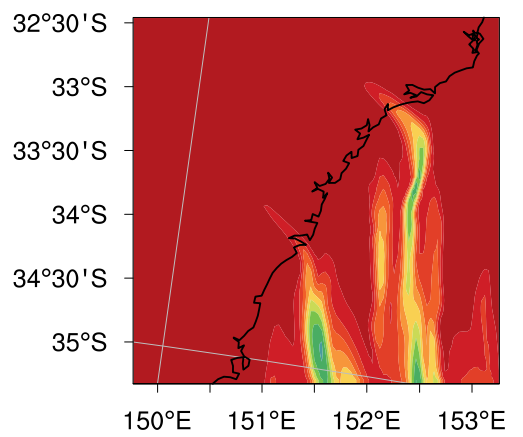

(a) 8 Jan 2013

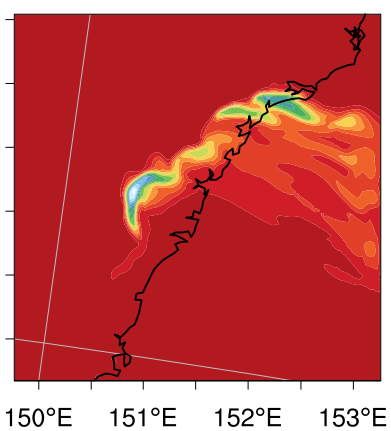

(b) 12 Jan 2013

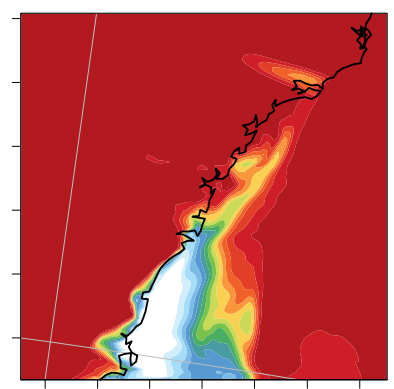

$150^{\circ} \mathrm{E} \quad 151^{\circ} \mathrm{E} \quad 152^{\circ} \mathrm{E} \quad 153^{\circ} \mathrm{E}$

(c) 18 Jan 2013

PAN difference (ppbv)

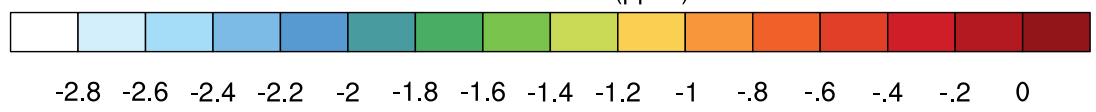

Figure 17. Simulated difference between PAN from standard run and PAN from average temperature run (STD_ET-AVG_T).

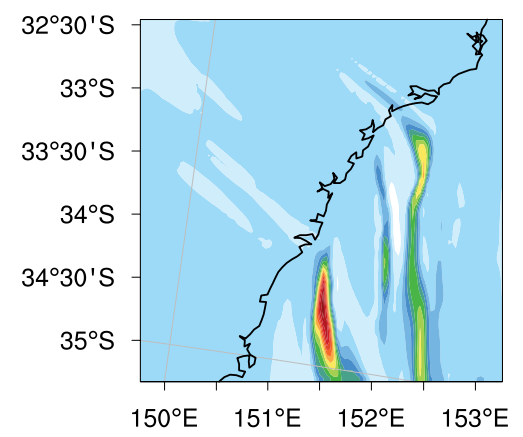

(a) 8 Jan 2013

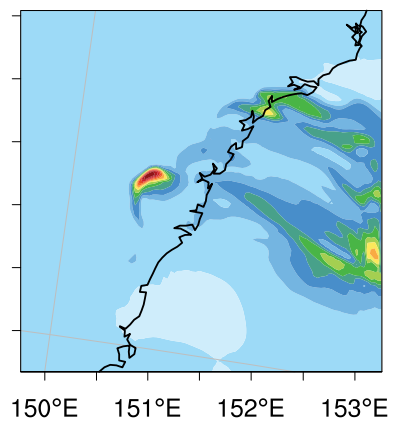

(b) 12 Jan 2013

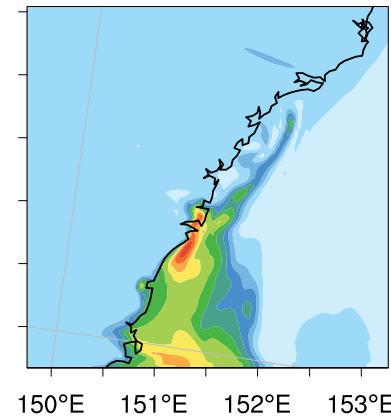

(c) 18 Jan 2013

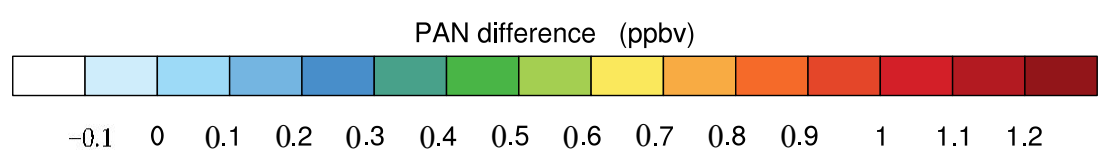

Figure 18. Simulated difference between PAN from standard run and PAN from average emissions run (STD_ET-AVG_E).

As already mentioned, in this study, we have assumed no change to water vapour mixing ratios for the average temperature run relative to the standard run so, we can discount the water vapour effect in these simulations. This assumption is partially consistent with the results from Sillman and Samson [13], who found the impact of water was negligible (simulated 54 and 53 ppbv ozone mixing ratios for runs with and without water corrections) for rural Michigan, although they found a very large water vapour effect for Detroit (75 and $107 \mathrm{ppbv}$ with and without water correction, respectively). However, other studies have shown the opposite effect (negative for rural areas but mixed for polluted environments) of temperature on ozone via its effect on humidity $[59,60]$. Due to its proximity to the presence of biogenic sources in Greater Sydney, the atmospheric composition in Greater Sydney may be more similar to rural Michigan than Detroit. Future work will account for changes in water vapour mixing ratio to determine the impact on photolysis rates.

In our study, we have looked at the effect of temperature on biogenic emissions and not on anthropogenic emissions. Studies have shown that some anthropogenic emissions are also affected by 
temperature, such as $\mathrm{NO}_{x}$ emissions from soils (e.g., [61]) (e.g., from nitrogen fertilisers). However, the temperature dependency of biogenic emissions is stronger.

\subsubsection{Ozone Sensitivity to Biogenic Emissions}

Figure 19 shows a comparison of measured and simulated $\mathrm{O}_{3}, \mathrm{NO}_{2}, \mathrm{HCHO}$ and isoprene mixing ratios at the MUMBA site (the only site where isoprene and $\mathrm{HCHO}$ were measured [24]; see Figure 1 for location). As we saw earlier, the model under-predicts ozone in the early phase of the study period from 8 January to 14 January, despite over-predicting isoprene. This could be due to $\mathrm{NO}_{x}$-limited conditions as the model also generally under-predicts $\mathrm{NO}_{2}$ as shown in Figure 19d. Compared with the measured isoprene, the model over-predicts isoprene even for the case when isoprene emissions are halved. Unfortunately, during the extreme temperature episode of 18 January, the instruments failed due to the extreme heat and thus we do not have complete measurement data during this day. Running the model with halved isoprene emissions has the effect of decreasing simulated ozone during the extreme temperature days by as much as $30 \mathrm{ppbv}$ (e.g., during the 18 January extreme heat period) below the standard run. The effect of halving biogenic emissions is only significant during the extreme heat days. For the non-extreme heat days, the simulated ozone for the various emission scenarios is not much different from the standard run. The ozone timeseries shown in Figure 19a also shows that running the model with zero biogenic emissions has the effect of completely removing ozone episodes during the extreme heat days, which shows the impact of biogenics especially during periods of extreme temperatures. Timeseries of observed and simulated HCHO (a byproduct of isoprene oxidation, Figure 19c) show increased mixing ratios during the extreme heat periods as expected from the increased photochemistry and with the increased isoprene emissions. It is interesting to note that, although the model over-predicts isoprene during the extreme heat period on 8 January, it still under-predicts both ozone and $\mathrm{HCHO}$, which can be attributed to $\mathrm{NO}_{x}$-limited conditions (see Figure $19 \mathrm{~d}$ ) in the model. These $\mathrm{NO}_{x}$-limited conditions are in agreement with a study by Linfoot et al. [20] who analysed ozone exeedances between 1998 and 2003 using an Integrated Empirical Rate model. They found that the majority of the events were in the $\mathrm{NO}_{x}$-limited regime especially for western Sydney.

Table 6 shows the regression statistics from the measured and simulated $\mathrm{O}_{3}, \mathrm{NO}_{2}, \mathrm{HCHO}$ and isoprene during the MUMBA campaign. For $\mathrm{O}_{3}$, going from zero emission factor $(\mathrm{EF})=0.0$ ) to standard $(\mathrm{EF}=1.0)$ biogenic emissions increases the slope from 0.2 to $0.6 \mathrm{ppbv} \mathrm{ppv}^{-1}$ with a reduction in negative mean bias from $-6 \mathrm{ppbv}$ to $-5 \mathrm{ppbv}$. The correlation coefficient is improved from 0.4 to 0.6 . Comparing the half $(\mathrm{EF}=0.5)$ and the standard $(\mathrm{EF}=1.0)$ biogenic emissions runs, there is not much change in the sensitivity of ozone to the increase in isoprene, with the slope increased by $0.1 \mathrm{ppbv}$ $\mathrm{ppbv}^{-1}$ from $0.5 \mathrm{ppbv} \mathrm{ppbv}^{-1}$ and mean bias increased by $0.6 \mathrm{ppbv}$. For HCHO, the agreement with observations improves as the biogenic emissions are increased, with the slope rising from $0.1 \mathrm{ppbv}$ $\mathrm{ppbv}^{-1}$ for zero biogenic emissions run to $0.9 \mathrm{ppbv} \mathrm{ppbv}^{-1}$ for the standard run, and a negative $\mathrm{MB}$ reduction from $-1.4 \mathrm{ppbv}$ to $-0.6 \mathrm{ppbv}$. Isoprene is over-predicted, with slopes of $1.6 \mathrm{ppbv} \mathrm{ppbv}^{-1}$ and $4.0 \mathrm{ppbv} \mathrm{ppbv}^{-1}$ and mean biases of $0.4 \mathrm{ppbv}$ and $1.5 \mathrm{ppbv}$ for the half and standard biogenic emissions runs, respectively. The model's over-prediction of isoprene is in agreement with Emmerson et al. [62], who found that the MEGAN model tends to over-predict isoprene emissions over southeast Australia by up to a factor of 6 . This is thought to be due to the fact that the high emission factors in MEGAN v2.1 are estimated from young Eucalypts, which may have higher emission fluxes than the population of older trees generally found in Australian ecosystems. 


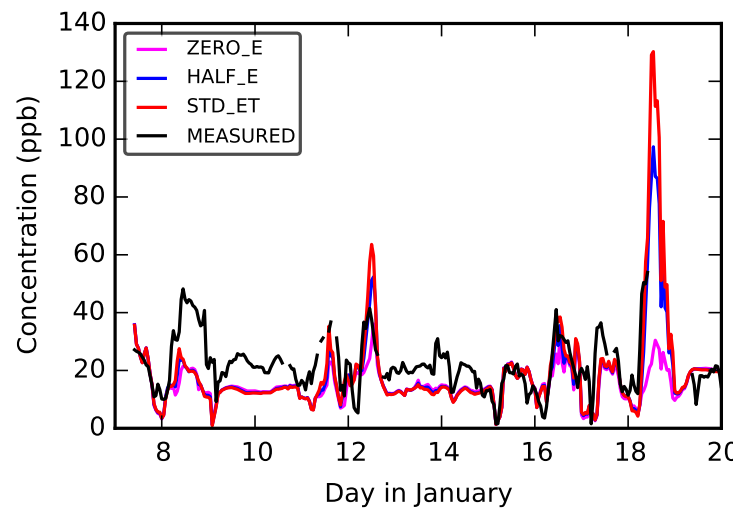

(a) $\mathrm{O}_{3}$

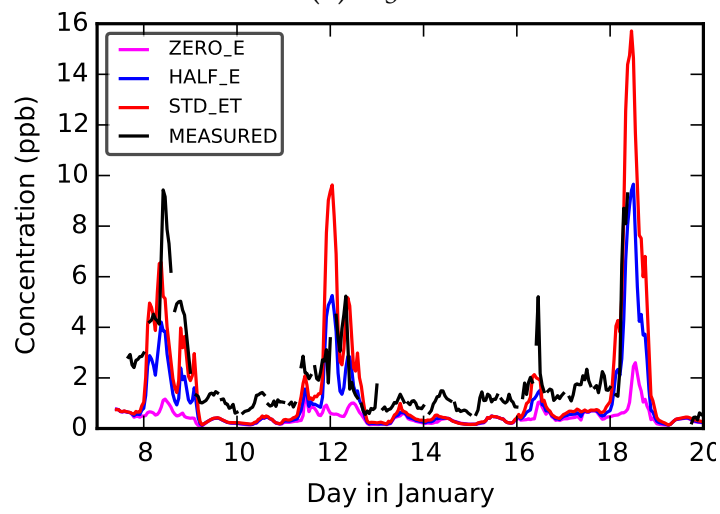

(c) $\mathrm{HCHO}$

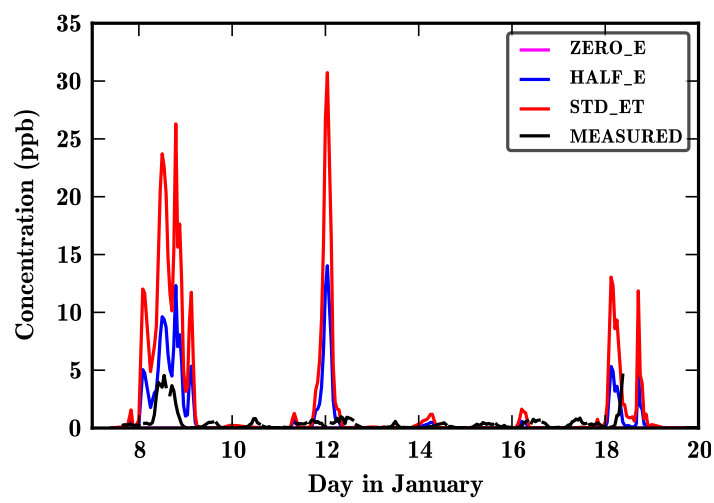

(b) Isoprene $\left(\mathrm{C}_{5} \mathrm{H}_{8}\right)$

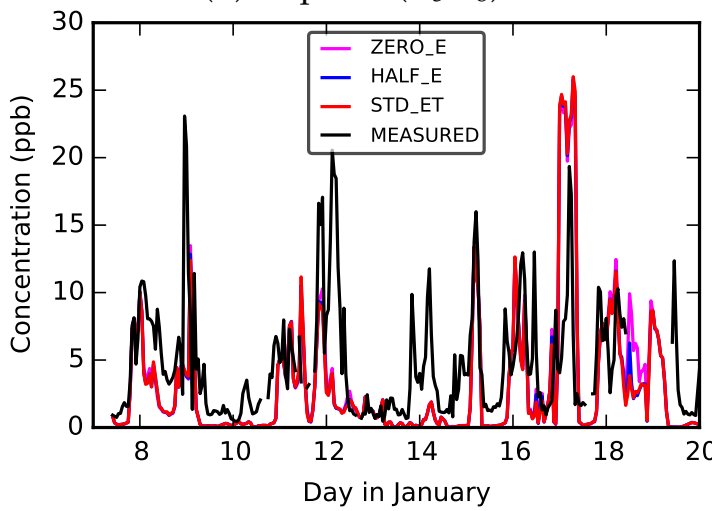

(d) $\mathrm{NO}_{2}$

Figure 19. Comparison of measured and simulated ozone, isoprene, formaldehyde and nitrogen dioxide at the MUMBA site in Greater Sydney.

Table 6. Table showing statistics for runs in which the biogenic emissions were scaled by various emission factors (EF).

\begin{tabular}{ccccc}
\hline Species & EF & Slope $\left(\mathbf{p p b v} \mathbf{p p b v}^{-\mathbf{1}}\right)$ & $\mathbf{R}$ & $\mathbf{M B}(\mathbf{p p b v )}$ \\
\hline \multirow{3}{*}{$\mathrm{O}_{3}$} & 0.0 & 0.2 & 0.4 & -6.0 \\
& 0.5 & 0.4 & 0.5 & -5.1 \\
& 1.0 & 0.6 & 0.6 & -4.6 \\
\hline \multirow{3}{*}{$\mathrm{NO}_{2}$} & 0.0 & 0.5 & 0.7 & -0.2 \\
& 0.5 & 0.5 & 0.7 & -0.1 \\
& 1.0 & 0.6 & 0.7 & -0.0 \\
\hline \multirow{3}{*}{$\mathrm{HCHO}$} & 0.0 & 0.1 & 0.6 & -1.4 \\
& 0.5 & 0.5 & 0.8 & -1.0 \\
& 1.0 & 0.9 & 0.8 & -0.6 \\
$\mathrm{C}_{5} \mathrm{H}_{8}$ & 0.5 & 1.6 & 0.6 & 0.4 \\
& 1.0 & 4.0 & 0.6 & 1.5 \\
\hline
\end{tabular}

\section{Conclusions}

In this study, the WRF-Chem model was used to simulate mixing ratios of atmospheric pollutants in Greater Sydney during the January 2013 extreme heat episodes that broke previously long-held temperature records. WRF-Chem is able to predict ozone and its precursors and these are compared with observations from a network of measurements in Greater Sydney. Under the predominantly $\mathrm{NO}_{x}$-limited conditions of Greater Sydney, the model simulates ozone with reasonable skill. We conducted a sensitivity study with the model to assess the relative and combined impacts of temperature and biogenic emissions on the simulated air quality during the extreme heat periods. 
The link between air quality and temperature is supported by many observational and modelling studies. Results from our modelling study have confirmed the relative and combined impacts of temperature and biogenic emissions on air quality especially during extreme heat periods. Our modelling study has shown that relative impacts of temperature and biogenic emissions are largely additive. The results also suggest that the effect of temperature on air quality is as large as the effect of biogenic emissions, with reductions in ozone mixing ratio of up to 8 and $10 \mathrm{ppbv}$ for separate temperature and biogenic emissions reductions, respectively, during periods of extreme heat.

Based on the isoprene measurements at a single site in Greater Sydney, we have seen that our model over-predicts isoprene. Therefore, it is conceivable that the relative effect of temperature on both chemistry and emissions will be reduced under a more realistic (i.e., less) simulated isoprene. Nevertheless, the role of biogenics in driving air pollution is demonstrated by running the model with zero biogenic emissions, which removes all simulated ozone episodes (even during the extreme heat days) and results in simulation of background ozone mixing ratios in the range of 10-30 ppbv. Clearly, more work should be directed at improved simulation of biogenic emissions in order to better estimate their impacts on air quality in Australia. Our study has shown the potential impact of temperature on biogenic emissions and how this can lead to poor air quality especially during extreme heat periods. However, it appears that the conditions in Greater Sydney (and most of Australia) are $\mathrm{NO}_{x}$-limited, which is fortuitous as it limits the generation of potentially higher ozone mixing ratios in areas in close proximity to biogenic emitters (such as Eucalyptus trees). Clearly, this has policy implications, especially with regard to what type of vegetation to choose for urban greening programs.

Although current levels of air quality in Australia are generally quite good, climate change will increase the frequency of extreme temperature events and thereby contribute to a worsening of air quality in the future through changes to both biogenic emissions and temperature-mediated atmospheric chemistry.

Author Contributions: Conceptualization, S.R.U. and P.J.R.; Methodology, S.R.U. and P.J.R.; Software, S.R.U. and P.J.R. and J.D.S.; Formal Analysis, S.R.U.; Resources, S.R.U., J.D.S., E.-A.D.G., K.M.E., M.C., C.P.-W., H.D., K.M. and Y.S.; Data Curation, S.R.U. and J.D.S.; Writing-Original Draft Preparation, S.R.U.; Writing-Review and Editing, S.R.U., P.J.R., J.D.S., E.-A.D.G., J.A.F., K.M.E., M.C., C.P.-W. and A.D.G.; Visualization, S.R.U.; Supervision, P.J.R.; Project Administration, P.J.R. and C.P.-W.; Funding Acquisition, P.J.R. and C.P.-W.

Funding: This research is supported by the Australian Government's National Environmental Science Program through the Clean Air and Urban Landscapes Hub. It was also supported by computational resources provided by the Australian Government through NCI under the National Computational Merit Allocation Scheme.

Conflicts of Interest: The authors declare no conflict of interest.

\author{
Abbreviations \\ The following abbreviations are used in this manuscript: \\ WRF-Chem Weather Research and Forecasting Chemistry model \\ MEGAN Model of Emissions of Gases and Aerosols from Nature \\ EF Emission Factor \\ STD_ET Standard (or normal) Emissions and Temperatures \\ AVG_E Average Emissions \\ AVG_T Average Temperatures \\ AVG_ET Average Emissions and Temperatures \\ BoM Bureau of Meteorology \\ NSW OEH New South Wales Office of Environment and Heritage \\ PBL Planetary Boundary Layer \\ VOC Volatile Organic Compound \\ MUMBA Measurements of Urban, Marine and Biogenic Air
}




\section{References}

1. Landrigan, P.J.; Fuller, R.; Acosta, N.J.R.; Adeyi, O.; Arnold, R.; Basu, N.N.; Baldé, A.B.; Bertollini, R.; Bose-O'Reilly, S.; Boufford, J.I.; et al. The Lancet Commission on pollution and health. Lancet 2018, 391, 462-512. [CrossRef]

2. Theoharatos, G.; Pantavou, K.; Mavrakis, A.; Spanou, A.; Katavoutas, G.; Efstathiou, P.; Mpekas, P.; Asimakopoulos, D. Heat waves observed in 2007 in Athens, Greece: Synoptic conditions, bioclimatological assessment, air quality levels and health effects. Environ. Res. 2010, 110, 152-161. [CrossRef] [PubMed]

3. Stedman, J.R. The predicted number of air pollution related deaths in the UK during the August 2003 heatwave. Atmos. Environ. 2004, 38, 1087-1090. [CrossRef]

4. Horton, D.E.; Skinner, C.B.; Singh, D.; Diffenbaugh, N.S. Occurrence and persistence of future atmospheric stagnation events. Nat. Clim. Chang. 2014, 4, 698-703. [CrossRef] [PubMed]

5. Hou, P.; Wu, S. Long-term Changes in Extreme Air Pollution Meteorology and the Implications for Air Quality. Sci. Rep. 2016, 6, 23792. [CrossRef] [PubMed]

6. Silva, R.A.; West, J.J.; Lamarque, J.F.; Shindell, D.T.; Collins, W.J.; Faluvegi, G.; Folberth, G.A.; Horowitz, L.W.; Nagashima, T.; Naik, V.; et al. Future global mortality from changes in air pollution attributable to climate change. Nat. Clim. Chang. 2017, 7, 647-651. [CrossRef] [PubMed]

7. Health Effects Institute. State of Global Air 2017: A Special Report on Global Exposure to Air Pollution and Its Disease Burden; Report; Health Effects Institute: Cambridge, MA, USA, 2017.

8. Keywood, M.; Hibberd, M.; Emmerson, K. Australia State of the Environment 2016: Atmosphere, Independent Report to the Australian Government Minister for the Environment and Energy; Report; Australian Government Department of the Environment and Energy: Canberra, Australia, 2017.

9. Hu, W.; Mengersen, K.; McMichael, A.; Tong, S. Temperature, air pollution and total mortality during summers in Sydney, 1994-2004. Int. J. Biometeorol. 2008, 52, 689-696. [CrossRef] [PubMed]

10. Broome, R.A.; Fann, N.; Cristina, T.J.; Fulcher, C.; Duc, H.; Morgan, G.G. The health benefits of reducing air pollution in Sydney, Australia. Environ. Res. 2015, 143, 19-25.[CrossRef] [PubMed]

11. Guenther, A.B.; Zimmerman, P.R.; Harley, P.C.; Monson, R.K.; Fall, R. Isoprene and monoterpene emission rate variability: Model evaluations and sensitivity analyses. J. Geophys. Res. Atmos. 1993, 98, 12609-12617. [CrossRef]

12. Seinfeld, J.; Pandis, S. Atmospheric Chemistry and Physics: From Air Pollution to Climate Change; Wiley: New York, NY, USA, 2016.

13. Sillman, S.; Samson, P.J. Impact of temperature on oxidant photochemistry in urban, polluted rural and remote environments. J. Geophys. Res. Atmos. 1995, 100, 11497-11508. [CrossRef]

14. Xing, J.; Wang, J.; Mathur, R.; Wang, S.; Sarwar, G.; Pleim, J.; Hogrefe, C.; Zhang, Y.; Jiang, J.; Wong, D.C.; et al. Impacts of aerosol direct effects on tropospheric ozone through changes in atmospheric dynamics and photolysis rates. Atmos. Chem. Phys. 2017, 17, 9869-9883. [CrossRef] [PubMed]

15. Chang, C.C.; Shao, M.; Chou, C.C.K.; Liu, S.C.; Wang, J.L.; Lee, K.Z.; Lai, C.H.; Zhu, T.; Lin, P.H. Biogenic isoprene and implications for oxidant levels in Beijing during the 2008 Olympic Games. Atmos. Chem. Phys. Discuss. 2013, 13, 25939-25967. [CrossRef]

16. Dickerson, R.R.; Kondragunta, S.; Stenchikov, G.; Civerolo, K.L.; Doddridge, B.G.; Holben, B.N. The Impact of Aerosols on Solar Ultraviolet Radiation and Photochemical Smog. Science 1997, 278, 827-830. [CrossRef] [PubMed]

17. Jiang, N.; Betts, A.; Riley, M. Summarising climate and air quality (ozone) data on self-organising maps: A Sydney case study. Environ. Monit. Assess. 2016, 188, 103. [CrossRef] [PubMed]

18. Corchnoy, S.B.; Atkinson, R. Kinetics of the gas-phase reactions of hydroxyl and nitrogen oxide $\left(\mathrm{NO}_{3}\right)$ radicals with 2-carene, 1,8-cineole, p-cymene, and terpinolene. Environ. Sci. Technol. 1990, 24, 1497-1502. [CrossRef]

19. Ritchie, G. Atmospheric Chemistry: From the Surface to the Stratosphere; Essential Textbooks in Chemistry; World Scientific: London, UK, 2017.

20. Linfoot, S.; Quigley, S.; Riley, M. Ozone events in Sydney-Implications for standard setting and investigation of control strategies. In Proceedings of the 17th International Clean Air \& Environment Conference, Hobart, Tasmania, 3-6 May 2005. [CrossRef] 
21. Benjamin, M.T.; Sudol, M.; Bloch, L.; Winer, A.M. Low-emitting urban forests: A taxonomic methodology for assigning isoprene and monoterpene emission rates. Atmos. Environ. 1996, 30, 1437-1452. [CrossRef]

22. Elliot, W.R.; Jones, D.L. Encyclopaedia of Australian Plants Suitable for Cultivation; Lothian Publishing Company Pty Ltd.: Port Melbourne, Australia, 1990; Volume 5.

23. Hager, T.; Benson, D. The Eucalypts of the Greater Blue Mountains World Heritage Area: Distribution, classification and habitats of the species of Eucalyptus, Angophora and Corymbia (family Myrtaceae) recorded in its eight conservation reserves. Cunninghamia J. Plant Ecol. East. Aust. 2010, 11, 425-444.

24. Paton-Walsh, C.; Guérette, E.A.; Kubistin, D.; Humphries, R.; Wilson, S.R.; Dominick, D.; Galbally, I.; Buchholz, R.; Bhujel, M.; Chambers, S.; et al. The MUMBA campaign: Measurements of urban, marine and biogenic air. Earth Syst. Sci. Data 2017, 9, 349-362. [CrossRef]

25. Givati, A.; Lynn, B.; Liu, Y.; Rimmer, A. Using the WRF Model in an Operational Streamflow Forecast System for the Jordan River. J. Appl. Meteorol. Climatol. 2012, 51, 285-299. [CrossRef]

26. Skamarock, W.C.; Klemp, J.B. A time-split nonhydrostatic atmospheric model for weather research and forecasting applications. J. Comput. Phys. 2008, 227, 3465-3485. [CrossRef]

27. Dee, D.P.; Uppala, S.M.; Simmons, A.J.; Berrisford, P.; Poli, P.; Kobayashi, S.; Andrae, U.; Balmaseda, M.A.; Balsamo, G.; Bauer, P.; et al. The ERA-Interim reanalysis: Configuration and performance of the data assimilation system. Q. J. R. Meteorol. Soc. 2011, 137, 553-597. [CrossRef]

28. Thiébaux, J.; Rogers, E.; Wang, W.; Katz, B. A New High-Resolution Blended Real-Time Global Sea Surface Temperature Analysis. Bull. Am. Meteorol. Soc. 2003, 84, 645-656. [CrossRef]

29. Emmons, L.K.; Walters, S.; Hess, P.G.; Lamarque, J.F.; Pfister, G.G.; Fillmore, D.; Granier, C.; Guenther, A.; Kinnison, D.; Laepple, T.; et al. Description and evaluation of the Model for Ozone and Related chemical Tracers, version 4 (MOZART-4). Geosci. Model Dev. 2010, 3, 43-67. [CrossRef]

30. Stauffer, D.R.; Seaman, N.L. Use of Four-Dimensional Data Assimilation in a Limited-Area Mesoscale Model. Part I: Experiments with Synoptic-Scale Data. Mon. Weather Rev. 1990, 118, 1250-1277. [CrossRef]

31. Chen, F.; Dudhia, J. Coupling an Advanced Land Surface-Hydrology Model with the Penn State-NCAR MM5 Modeling System. Part I: Model Implementation and Sensitivity. Mon. Weather Rev. 2001, 129, 569-585. [CrossRef]

32. Hong, S.Y.; Noh, Y.; Dudhia, J. A New Vertical Diffusion Package with an Explicit Treatment of Entrainment Processes. Mon. Weather Rev. 2006, 134, 2318-2341. [CrossRef]

33. Lin, Y.L.; Farley, R.D.; Orville, H.D. Bulk Parameterization of the Snow Field in a Cloud Model. J. Clim. Appl. Meteorol. 1983, 22, 1065-1092. [CrossRef]

34. Mlawer, E.J.; Taubman, S.J.; Brown, P.D.; Iacono, M.J.; Clough, S.A. Radiative transfer for inhomogeneous atmospheres: RRTM, a validated correlated-k model for the longwave. J. Geophys. Res. Atmos. 1997, 102, 16663-16682. [CrossRef]

35. Monin, A.S.; Obukhov, A. Basic laws of turbulent mixing in the surface layer of the atmosphere. Contrib. Geophys. Inst. Acad. Sci. USSR 1954, 151, 163-187.

36. Chou, M.; Suarez, M. An Efficient Thermal Infrared Radiation Parameterization for Use in General Circulation Models; Technical Report; NASA Technical Memorandum: Greenbelt, MD, USA, 1994.

37. Grell, G.A.; Dévényi, D. A generalized approach to parameterizing convection combining ensemble and data assimilation techniques. Geophys. Res. Lett. 2002, 29, 38-1-38-4. [CrossRef]

38. Stockwell, W.R.; Kirchner, F.; Kuhn, M.; Seefeld, S. A new mechanism for regional atmospheric chemistry modeling. J. Geophys. Res. Atmos. 1997, 102, 25847-25879. [CrossRef]

39. Ackermann, I.J.; Hass, H.; Memmesheimer, M.; Ebel, A.; Binkowski, F.S.; Shankar, U. Modal aerosol dynamics model for Europe: Development and first applications. Atmos. Environ. 1998, 32, 2981-2999. [CrossRef]

40. Schell, B.; Ackermann, I.J.; Hass, H.; Binkowski, F.S.; Ebel, A. Modeling the formation of secondary organic aerosol within a comprehensive air quality model system. J. Geophys. Res. Atmos. 2001, 106, 28275-28293. [CrossRef]

41. Janssens-Maenhout, G.; Dentener, F.; van Aardenne, J.; Monni, S.; Pagliari, V.; Orlandini, L.; Klimont, Z.; Kurokawa, J.; Akimoto, H.; O'Hara, T.; et al. EDGAR-HTAP: A Harmonized Gridded Air Pollution Emission Dataset Based on National Inventories; European Commission: Brussels, Belgium, 2012. [CrossRef]

42. Ginoux, P.; Chin, M.; Tegen, I.; Prospero, J.M.; Holben, B.; Dubovik, O.; Lin, S.J. Sources and distributions of dust aerosols simulated with the GOCART model. J. Geophys. Res. Atmos. 2001, 106, 20255-20273. [CrossRef] 
43. Chin, M.; Ginoux, P.; Kinne, S.; Torres, O.; Holben, B.N.; Duncan, B.N.; Martin, R.V.; Logan, J.A.; Higurashi, A.; Nakajima, T. Tropospheric Aerosol Optical Thickness from the GOCART Model and Comparisons with Satellite and Sun Photometer Measurements. J. Atmos. Sci. 2002, 59, 461-483. [CrossRef]

44. Guenther, A.; Karl, T.; Harley, P.; Wiedinmyer, C.; Palmer, P.I.; Geron, C. Estimates of global terrestrial isoprene emissions using MEGAN (Model of Emissions of Gases and Aerosols from Nature). Atmos. Chem. Phys. 2006, 6, 3181-3210. [CrossRef]

45. Steffen, W. Angry Summer 2013/2014: Climate Council; Climate Council of Australia Limited: Potts Point, Australia, 2014.

46. Seidel, D.J.; Zhang, Y.; Beljaars, A.; Golaz, J.C.; Jacobson, A.R.; Medeiros, B. Climatology of the planetary boundary layer over the continental United States and Europe. J. Geophys. Res. Atmos. 2012, 117. [CrossRef]

47. Engel, C.B.; Lane, T.P.; Reeder, M.J.; Rezny, M. The meteorology of Black Saturday. Q. J. R. Meteorol. Soc. 2013, 139, 585-599. [CrossRef]

48. Monk, K.; Guérette, E.A.; Utembe, S.; Silver, J.D.; Emmerson, K.; Griffiths, A.; Duc, H.; Chang, L.T.C.; Trieu, T.; Jiang, N.; et al. Evaluation of regional air quality models over Sydney, Australia: Part 1 Meteorological model comparison. Atmosphere 2018, submitted.

49. Neirynck, J.; Gielen, B.; Janssens, I.A.; Ceulemans, R. Insights into ozone deposition patterns from decade-long ozone flux measurements over a mixed temperate forest. J. Environ. Monit. 2012, 14, 1684-1695. [CrossRef] [PubMed]

50. Stjernberg, A.C.E.S.E.; Skorokhod, A.; Paris, J.; Elansky, N.; Nédélec, P.; Stohl, A. Low concentrations of near-surface ozone in Siberia. Tellus B Chem. Phys. Meteorol. 2012, 64, 11607. [CrossRef]

51. Paris, J.D.; Stohl, A.; Ciais, P.; Nédélec, P.; Belan, B.D.; Arshinov, M.Y.; Ramonet, M. Source-receptor relationships for airborne measurements of $\mathrm{CO}_{2}, \mathrm{CO}$ and $\mathrm{O}_{3}$ above Siberia: A cluster-based approach. Atmos. Chem. Phys. 2010, 10, 1671-1687. [CrossRef]

52. Sillman, S.; Logan, J.A.; Wofsy, S.C. The sensitivity of ozone to nitrogen oxides and hydrocarbons in regional ozone episodes. J. Geophys. Res. Atmos. 1990, 95, 1837-1851. [CrossRef]

53. Stone, D.; Whalley, L.K.; Heard, D.E. Tropospheric $\mathrm{OH}$ and $\mathrm{HO}_{2}$ radicals: Field measurements and model comparisons. Chem. Soc. Rev. 2012, 41, 6348-6404. [CrossRef] [PubMed]

54. Tan, J.; Zheng, Y.; Tang, X.; Guo, C.; Li, L.; Song, G.; Zhen, X.; Yuan, D.; Kalkstein, A.J.; Li, F.; et al. The urban heat island and its impact on heat waves and human health in Shanghai. Int. J. Biometeorol. 2010, 54, 75-84. [CrossRef] [PubMed]

55. Li, D.; Bou-Zeid, E. Synergistic Interactions between Urban Heat Islands and Heat Waves: The Impact in Cities Is Larger than the Sum of Its Parts. J. Appl. Meteorol. Climatol. 2013, 52, 2051-2064.[CrossRef]

56. Levy, H.; Mahlman, J.D.; Moxim, W.J.; Liu, S.C. Tropospheric ozone: The role of transport. J. Geophys. Res. Atmos. 1985, 90, 3753-3772. [CrossRef]

57. Chou, C.C.K.; Tsai, C.Y.; Chang, C.C.; Lin, P.H.; Liu, S.C.; Zhu, T. Photochemical production of ozone in Beijing during the 2008 Olympic Games. Atmos. Chem. Phys. 2011, 11, 9825-9837. [CrossRef]

58. Fischer, E.V.; Jacob, D.J.; Yantosca, R.M.; Sulprizio, M.P.; Millet, D.B.; Mao, J.; Paulot, F.; Singh, H.B.; Roiger, A.; Ries, L.; et al. Atmospheric peroxyacetyl nitrate (PAN): A global budget and source attribution. Atmos. Chem. Phys. 2014, 14, 2679-2698. [CrossRef]

59. Dawson, J.P.; Adams, P.J.; Pandis, S.N. Sensitivity of ozone to summertime climate in the eastern USA: A modeling case study. Atmos. Environ. 2007, 41, 1494-1511. [CrossRef]

60. Davis, J.; Cox, W.; Reff, A.; Dolwick, P. A comparison of CMAQ-based and observation-based statistical models relating ozone to meteorological parameters. Atmos. Environ. 2011, 45, 3481-3487. [CrossRef]

61. Yienger, J.J.; Levy, H. Empirical model of global soil-biogenic NOx emissions. J. Geophys. Res. Atmos. 1995, 100, 11447-11464. [CrossRef]

62. Emmerson, K.M.; Galbally, I.E.; Guenther, A.B.; Paton-Walsh, C.; Guerette, E.A.; Cope, M.E.; Keywood, M.D.; Lawson, S.J.; Molloy, S.B.; Dunne, E.; et al. Current estimates of biogenic emissions from eucalypts uncertain for southeast Australia. Atmos. Chem. Phys. 2016, 16, 6997-7011. [CrossRef]

(C) 2018 by the authors. Licensee MDPI, Basel, Switzerland. This article is an open access article distributed under the terms and conditions of the Creative Commons Attribution (CC BY) license (http://creativecommons.org/licenses/by/4.0/). 